\title{
ARTICLES
}

\section{Caught Between Tradition and Modernity: East Asia at The Hague Peace Conferences}

\section{Arthur Eyffinger*}

The 1907 Hague Conference was the single ever global summit before WW I to critically evaluate the interaction of the worlds of law and diplomacy. Pivotal to its debate was the Russo-Japanese War which suggested no less than eleven out of its thirteen Conventions. The crystallization of fifty years of Western interference in the Far East, the war heralded the end of an Era, sealing the fate of the legendary Chinese and Korean empires and putting Japan on its course to imperialism. This paper recapitulates the historical options available to China, Korea and Japan, reviews causes and consequences of their separate stands, and evaluates their critical relevance to the Hague debate.

\section{Relevance and Purport}

\section{A. A Paradox}

The paramount import of the two Hague Peace Conferences 1 for the current status of their host city can never be contested. To that extent, it is well to remember that, at the

* Director JUDICAP < www.judicap.com> The Hague. Ph.D. (Amsterdam). Former Head-Librarian of ICJ. Classicist and legal historian.

1 On the two Hague Peace Conferences see C. D. Davis, The United States and the First Hague Peace Conference (1962); the same author, The US and The Second Hague Peace Conference (1975); J. Dülffer, Regeln Gegen den Krieg? Die HaAger Friedens-Konferenzen 1899 und 1907 in der Internationalen Politik (1981); A. Eyffinger, The 1899 Hague Peace Conference: The Parliament of Man, The Federation of the World (1999); the same author, The 1907 Hague Peace Conference: The 
time, the option for The Hague was the outcome of a diplomatic deadlock in the ritual dance of the major Western powers and the result of a process of elimination rather than a deliberate choice, and an invitation not entirely welcomed by the host country. Even if the 1899 and 1907 summits of the then 'civilized' world overtly belied the widely shared illusions at the time that the Conferences would overturn geo-politics overnight, to the vacillating political centre of a backward country they lent a new lease on life and an undreamt-of role in world affairs. A full hundred years later, The Hague proudly presents itself to the world as its self-appointed judicial capital. Still, with all due respect, the Conferences themselves, in the final analysis, were more about Beijing, Tokyo and Seoul than ever they were about The Hague.

At face value, the above contention strikes as a paradox, to be belied by statistics to begin with. In 1899, out of the twenty-six delegations gathering in the legendary House in the Woods, only a handful were from outside that charmed circle of the Western World, the 'Concert' of nations which, by grace of race, religion and, more to the point, economic and military preponderance brazenly predicated itself as representing 'civilization.' The African world was never represented at all, neither in 1899 nor in 1907. It had been dealt with summarily in a previous venue, in Berlin in 1884-85, at a gathering which, without ever bothering to consult the voice of the Dark Continent, neatly wound up the European 'scramble' for that part of the globe. The LatinAmerican world, while proudly advertizing its European roots, a regional legal culture of its own and a process of unification which, in its endless ups and downs, only mirrored the European model, was blatantly underrepresented, with Mexico serving as its one and only advocate.

So what about Asia? Turkey, that 'dying man of Europe' with an ever shrinking foothold on both continents that had been hesitantly welcomed into the privileged elite at Paris in 1856, acted in The Hague as a kind of trait d' union between West and East, the worlds of Cross and Crescent, rather than as a strictly Asian power. Persia's presence had similar strategic reasons. Situated at the crossroads of rivalling European expansionism, it neatly obliged the power politics of the mighty.

Conscience of The Civilized World (2007); K. Schlichtmann, Japan, Germany and the Idea of The Hague Peace Conferences, 40 J. Peace Res. 377-94 (2003); 2007 commemorative issue of Neth. Int L L. Rev., Vol. LIV. For older literature, see J. H. Choate, The Two Hague Conferences (1913); A. P. Higgins, ed., The Hague Conferences and Other International Conferences Concerning the LaWs and Usages of War. Texts of Conventions with Notes (1904); W. I. Hull, The Two Hague Conferences and Their Contributions to International LaW (1908); A. Pillet, Les Conventions de la Haye 1899/1907 (1918); W. SchükIng, The International Union of The Hague Conferences (1918). Texts of the Conferences are found in J. B. Scott, ed., Texts of the Peace Conferences at The Hague 1899 and 1907 (1908); the same author ed., The Proceedings of The Hague Peace Conferences. Translation of the Official Texts Under the SUPERVISION OF- (1920). 
Most depressing of all perhaps, at this pivotal moment of history, with mankind allegedly in quest for unity for the sake of peace and prosperity, the populous Indian subcontinent which, in historical perspective, stood out as perhaps the world' s most inspiring role-model in attaining the ends at stake in The Hague was neither represented by delegation nor by ideology. Eminently representing a melting pot of cultures and the issue of an endless process of assimilation and digesting, a full three millennia earlier the sub-continent had given rise to the first ever sparks of truly global thinking in putting humanity first. Indian concepts had remoulded, indeed 'globalized' Greek thought of the Alexandrinian age as epitomized by the universal outlook of Stoicism, hence to make their indelible imprint on the Roman world, inspire Christian doctrine itself and finally prompt the natural law doctrine in the Grotian tradition to which so ready lip-service was paid in The Hague. Self-conceit from unchallenged military and economic superiority had long since turned the Western world myopic.

To that extent, the Far East seemed much nearer at home and, from the practical perspective of power politics, of more acute relevance to keen Western observers. In 1899, in The Hague, the region was represented by Japan, China and Siam, the only three East Asian nations so far to comply with the criterion for invitation of being represented on a permanent basis at the St. Petersburg court. Their status differed greatly, yet to the commoner in The Hague they indiscriminately presented the 'exotic' element, a mostly symbolic, folkloristic token of world coverage. Whereas, on the one hand, the Huis ten Bosch, in line with fashion of the period, boasted Chinese and Japanese salons, it was not so much their delegations that impressed media and Hague citizenry as rather the striking oriental beauty of the Chinese first delegate's family. For wieks on end, Yang Yü's pretty young wife,2 her make up, coiffures and oriental robes, ${ }^{3}$ and their three darling children 4 were the talk of the town.

2 Baroness Bertha Von Suttner, the undisputed head of the peace movement at the time and an acute observer, in her diaries never gets tired of admiring Yang Yü, s charming young wife, "a beauty who seems to have been cut out of a brilliant picture by a Chinese artist, and endowed with life by some Chinese Venus, touched by the entreaties of a Celestial Pygmalion" [...] "She is a pretty young woman, yet quite of the type which you see on Chinese porcelain; at the same time she is so heavily rouged that her face resembles a changeless enameled mask." [...] And yet there is a touch of lovableness in her pretty little face. Her gestures when she extends her hand are something like a wooden doll s; but then, she shakes the hands of other people so heartily that it seems to me 'For life, old comrade!'. For these and following references to Baroness Von Suttner see Bertha Von Suttner, Memoirs: the Record of an Eventful Life, 2 vols. (1910).

3 "The Chinese delegate's young wife wears her native costume, including an embroidered silk robe, a tiny cap on her head, and paper flowers on each side of her temples."

4 "Her son of twelve and her little daughter of eight, both also in Chinese costume, accompany her, and they bear the brunt of the conversation, for they speak both English and French. These children will not be brought up as pure unadulterated Chinese. Behind their wall lies henceforth for them a piece of the world - a world moreover, in which all nations are joined to treat together in the name of universal peace; this idea will 


\section{B. The Russian Conundrum}

However, appearances can be deceptive. Whereas the role of the Far Eastern delegations on this occasion was still mostly a passive one, and their participation in the debate fairly limited, already by then their presence can be shown to have been of acute pertinence. To illustrate this, we turn to the raison d' être of the Conference itself. The idea of a 'world conference' of the kind was first launched in London in 1887, when Lord Salisbury proposed the formidable 'head of Christianity' Czar Alexander III to invite the nations to a conference and discuss vexed issues of world affairs. Cut short by the Czar's premature death, the idea was abandoned, then to be resumed nearly two decades later by Czar Nicholas II of his own accord. For all the lofty notions encapsulated in the famous 'Rescript' of 1898 , and for all its ready acclaim by pacifists, it was a quest for peace from self-interest, and few were the ministries to be fooled.

The Rescript's immediate cause was a financial dilemma, triggered by yet another round in the pokerplay of that seemingly unstoppable armaments race in Europe with the introduction of a new machine gun by the French and Austrian armies. Still, the Rescript's ultimate rationale lurked deeper. In proposing a Conference to negotiate a five to ten years moratorium Russia, on the brink of bankruptcy and with social unrest brewing, wished to reserve all its assets to improve on the vast empire's notorious Achilles heel, its pathetic infrastructure. This, however, was never an end in itself. It merely served as premisse to Russia' s military and economic expansion.

Cartoons of the period, reflecting overall impression in Europe, depict Russia as an octopus spreading its tentacles in all directions. In fact, St. Petersburg aspirations, far from being pell-mell, were well-targeted. Their ends were threefold, and aimed, firstly, at securing all-year-through open water harbours for Russia's navy and merchant fleet; secondly, at satisfying its massive need of raw materials for the Empire's industrialization; and, thirdly, at opening up vast new export markets. Foremost targets to attain its first objective, warm water ports, were the Dardanelles and the Liaotung Peninsula. The rich Korean minerals featured high to satisfy the second objective, while Manchuria and China were pertinent towards the third.

The above explains Russia's rationale in meddling with the Balkans under the guise of Pan-Slavism so as to disintegrate the multi-national Austrian-Hungarian Hapsburg Empire. Its huge investments in a range of canals to link Baltic to Bosporus anticipated on this. This policy likewise accounts for its bid for Persian oil which it secured by its

remain all their lives bound up with the recollection of the sweetmeats ... offer[ed] them on a Delft plate." [...] "Gradually all Chinese walls - there are others than that one which bounds the Middle Kingdom - will fall. We already see them tottering." 
1907 Entente with England. Finally, and most pertinent to our present purposes, it was expansion towards the Far East that inspired, indeed justified in finance minister Witte' s eyes, the overcostly Trans-Siberian Railway programme which, tentativily launched in 1891, aspired at linking St. Petersburg all the way to Vladivostok.

The above may serve to illustrate the pertinency of the Far East to The Hague Debate of 1899 . By 1907 this perspective had only intensified. The eight years in-between had changed the world dramatically and bereft even the most steadfast champion of the European 'Concert' model of all illusions. To the puzzlement of the world, the previous century's two major boasts, the Nation-State and the Industrial Revolution had conspired into a deadly threat to civilization itself. Fratricides as between British and Boers or Northern Americans and their Latin counterparts, skirmishes in China and Venezuela and conflicts over Sudan and Morocco, by their accumulated effect, had eroded the credibility of the global political fabric.

In the year prior to the Second Conference the world was definitely not a happy place. In a society torn by decadence from complacency and anarchy from despair, revolt was ubiquitous. All through 1906, time-honoured empires and colonial powers were unbalanced by the sudden winds of change that seemed to have picked up in the wake of Japan's stunning victory over Russia. While Germany smothered revolts of Hottentots in pools of blood, Britain faced uprising Kaffirs in Natal and unrest in India. While the US imposed its rule on the Philippines and Cuba, Japan cruelly dealt with Korean calls for independence. Strikes and revolts raged from Bulgaria to Zululand and rumours of appalling massacres trickled in from the Congo. Crisis in the international arena was emphatically parallelled by the domestic sphere. 5 Throughout the last decade of what by some curious misnomer was called the Belle Epoque the world was a Society under Siege, in which distrust, deceit and delusion prevailed.

Keen apprehensions of European cabinets found an outlet in two ways. The first overall concern was to secure strategic alliances. The years are rightly called the Era of Diplomatic Revolution. Paramount among the spectacular reorientations of policies feature the Anglo-Japanese Alliance of 1902 and the Franco-Britisch Entente Cordiale of 1904. Whatever their other intentions, their never anticipated repercussions in disrupting the European Balance were enormous. The 1902 Alliance linked two formidable naval powers in the East in defiance of Russia. The 1904 Entente, in putting

5 While the Czar relentlessly smothered the calls for bread of the Moscow mobs and unwisely fooled successive Doumas, even the Persian shah felt compelled to comply with a constitution. As London suffragettes laid siege to the Houses of Parliament, women in Finland exacted passive and active suffrage. With French socialists tearing down the last bulwarks of conservatism in definitely separating State and Church, the Liberal cabinet in London risked its neck in curbing the powers of the House of Lords. Germany was aroused by scandals, Holland on the edge of financial crisis. 
an end to centuries of Franco-British rivalry and mistrust, lured the world's foremost naval power from its time-honoured position of 'splendid isolation' into an alliance which could not help rousing German suspicion. 6

The second, equally understandable reaction of cabinets, one born out of fear for war, was to try and find shelter under the scutcheon of the law. In the years between The Hague Conferences the number of arbitration treaties literally exploded. After a hesitant start, the pride of the 1899 Conference, the Permanent Court of Arbitration, definitely shifted into gear.7 The 1907 Conference only confirmed the apparent dichotomy of law and politics. Its signal successes in the legal domain were entirely nullified by its perfect failure to curb power politics. Still, while helpless in the short run to forestall the cataclysm that, ever imminent from 1890, eclipsed that phase of history in 1914, in the long run the Conference's impressive legal legacy grew into the core of 'The Hague Tradition' and consituted the intellectual backdrop for the Statutes of its current Courts and Tribunals.

\section{The Pertinence of the Far East}

In this all too sketchy and trivial overview of eight years brimmed with drama (18991907) we have left to the last the discussion of the two closely related elements that were of the most signal impact on the 1907 world summit, thus precisely to demonstrate the eminent relevance of our specific subject-matter, the Far East, to the overall interpretation of the Second Hague Conference. We refer to the 1902 Anglo-Japanese Alliance and the Russo-Japanese War of 1904-05. No single event even remotedly affected the Conference agenda in 1907 in the way the Russo-Japanese war did. Its endless violations of war codes and the numerous questions it raised concerning the latters' validity and applicability dominated The Hague debate from first to last. In all, no less than eleven out of its thirteen conventions were triggered by the war's devastating effects on warmongers and third parties.

The war itself was the natural and within the prevailing global political framework virtually inevitable outcome of the conflicting interests of two militarized, expansionistic powers. Still, it was the 1902 Alliance which had emboldened Japan to cast the die and risk the gamble of war, relying on British support to keep third parties from intervening. What came as a shock to the world at large was not so much the war itself as rather its

6 It challenged that reactionary bastion of militarism into vainly putting the Entente' $s$ substance to the test in a deliberately provoked crisis over Morocco. The backfiring of this policy at Algeciras in 1906 triggered further German fears of Einkreisung (by Russia, France and Great Britain). These actuated its naval rivalry with the UK that was to become one of the major incentives to WW I.

7 Eyffinger, supra note 1(2007), Chs. 1-2. 
outcome: the overnight déconfiture of a legendary world empire at the hands of an 'upstart' non-Western nation that showed itself Europe' s 'wizard apprentice.'

The war epitomized a process of some three decades in making Japan' $s$ aspirations come true to qualify as a fully-fledged 'civilized' power within the 'comity of nations.' As a consequence, Japan's status in 1907 was fundamentally different both from its own position in 1899 and from that of any other Asian nation at either of the two Hague Conferences. Rather, as would turn out, Japan' s new status went precisely at the cost of the two other political entities in the region to be reckoned with, China and Korea. So much so indeed that its sudden rise to prominence made Western powers readily join hands in countering the newcomer's ambitions.

Frustration in Japan at finding its, from its own perception, justified demands curbed by Western powers was first engendered in 1895 when, in the wake of its war with China, it found itself tricked out of Manchuria by a Triple Intervention of Western powers. Suspicion was resuscitated after the Boxer Revolt in 1900, when it felt its efforts to help quench rebellion were not sufficiently rewarded, and was not exactly appeased by its first negative experience with the Permanent Court of Arbitration (PCA) in the Japanese House Tax case (1902-05). Suspicion was proven right at the conference table in 1905. 'Portsmouth' prompted serious riots in Tokyo for months on end. These accumulated grievances triggered the anti-Western feelings and militarism that would seriously affect the region in the next half-century.

That period, obviously, is well beyond the limited scope of this paper. However, the half century preceding The Hague Conferences cannot be dismissed here with impunity. It was the very different policies generated by China, Japan and Korea respectively in addressing Western meddling over 1850-1900 and their failure to develop a common strategy that led to their infighting and separate stands at The Hague in 1907 - indeed to the point of creating for themselves a most embarrassing incident regarding the Korean delegation. 8 'Asia' as such had no standing or role of any consequence at The Hague Conferences. There was never a link between the policies of the Far Eastern nations and Siam, Persia or Turkey. Nor did these last three nations pose any acute interests, problems or challenges to the great powers in connection, however

8 On that same occasion, by comparison, 12 nations from the Latin-American world, all but one (Mexico) newcomers to the Conference, in spite of obvious internal rivalry as between Brazil and Argentina, made a very impressive stand at The Hague. They warmly advocated the innate legal traditions of their region and, for all intimidation by the Great Powers, stubbornly insisted on the strictest equality of all sovereign states actually turning tables as in the debate on arbitration courts. In this, they showed remarkable legal expertise and wit, and considerable powers of rhetoric and eloquence at that, in countering European pressure. More than this, they vied with each other in offering banquets and receptions at The Hague hotels and restaurants. 
remote, to the Far East. 9 By contradistinction, the Far East itself was, from first to last, at the heart of the debate. In this process, sadly enough, the three nations acutely involved - be this in a predominantly active or passive way, as actor or victim, never made a common front, and this to the cultural and political detriment of the region.

In this paper we intend to review, compare and evaluate the causes for the specific reactions of the three nations on Western imperialism and the consequences of these policies for The Hague Conferences. In view of the limited purport of this paper, we feel entitled in dealing with the other Asian delegations in The Hague merely in passing. We will start by briefly addressing the early dealings of the Far East with the West and modernity as such.

\section{The Dawn of A New Era ${ }^{10}$}

To some extent, and mutatis mutandis, early experience with international law and relations in the Far East had run along somewhat parallel lines with Europe. In the days of the Greek city-states the Chinese commonwealth in its Spring and Autumn Period knew an equally beneficial interplay of diplomacy and the law. It featured the mechanisms of mediation and arbitration and the reliance on a league system to monitor the use of interstate force and the settlement of disputes. However, just like after Pydna (168 BC) stern Roman rule was implanted on the world of Hellenism and 'unequal,' 'leonine' treaties were enforced indiscriminately, in China, in much the same way, by 221 BC the Warring States system was replaced with the monolith empire and an essentially tributary system imposed on the neigbouring areas. Still, as everywhere, the rule never went unchallenged. At regular intervals, successive

$9 \quad$ As will be seen later, the Anglo-Russian Entente which o.a. dealt with Persia, Ethiopea and Tibet, was concluded during, but well kept out of sight of the 1907 Conference, with Persia not being notified at all.

10 Literature, clearly, is overwhelming. For some recent appraisals see K. Akashi, Japanese Aceptance of the European Law of Nations: A Brief History of International Law in Japan 1853-1900, in M. STOLLEIS \& M. Yanagihara eds., East Asian and European Perspectives on International LaW 1-21 (2004); R.P Anand, Family of "Civilized" States and Japan: A Story of Humiliation, Assimilation, Defiance and Confrontation, 5 J. His. Int’ L L. 1-75 (2003); H. Sim, Brutal Internal Struggle against External Imperialism: The Initial Phases in the Reception of Western LaW into Korean Society in the 1890s, in M. Stolleis / M. Yanagihara eds., id. 23-40; R. Svarverud, International LaW as World Order in Late Imperial China; Translation, Reception And Discourse, 1847-1911 (2007); Wang Tieya, International law in China: Historical and Contemporary Perspectives, in 221 REcueIL DE CouRs 195-370 (1990/2); Eric Yong-Joong Lee, Early Development of Modern International Law in East Asia - With Special Reference to China, Japan and Korea, 4 J. His. INT' L L. 42-76 (2002). 
dynasties had to cope with succesful inroads on the Chinese mainland and the Korean peninsula from a recalcitrant Japan. Sources suggest instances of diplomacy on a fairly equal footing. In all likelihood, a stable customary international legal order based on state practice prevailed until, at around the opening of the Qing era (1644 AD), Western interference changed horizons.

\section{A. China}

Portuguese envoys and Jesuit missionaries - purse and bible, 'greed and godliness' had reached the Chinese mainland well over a century before, to find their 'barbaric' overtures disdainfully rejected.11 Predictably, the Dutch were to follow suit, but they never made much headway either. The Empire by then constituted a self-contained, economically self-sufficient land society, averse to overseas trade and playing deaf to European legal concepts. In international legal terms the Empire' s entrance into the modern era opens with the 1689 Chinese-Russian Treaty of Nerchinsk. This pact on equal terms strikes as the more surprising inasmuch as, a full century later (1793), with China once more withdrawn into stubborn seclusion, the British ambassador Lord Macartney, when making trade overtures, was dismissed offhand as just another barbarian tributary - not with impunity this time. Through the Empire' s only outlet in Canton the British, regardless of official bans, opened their profitable exchange of Indian opium for Chinese tea and, when put to the test, in 1839 readily waged war on the vacillating Empire.

By 1842 the British effectively turned tables and imposed terms of their own in the 'unequal' Treaty of Nanking, thereby securing trade ports and enforcing the opening of a first diplomatic mission. Inevitably, other Western powers, notably the US and France, 12 followed suit, likewise claiming 'most-favoured-nation' status. Soon Western settlements with powers of extraterritoriality put an end to the Canton trade system and the era of Chinese seclusion. Willy-nilly the Empire opened up to modern legal concepts, a process distinctly accelerated in 1861 with the Qing Restoration. A college of foreign languages was opened, Western advisers were recruited and haphazardly Chinese scholars ventured abroad. Reputedly, translations of treatises by such Western luminaries as Von Martens, 13 Wheaton, 14 and Bluntschli15 were effective instruments of

11 To that extent, 19th century European positivistic concepts of civilization were prefigured by Chinese concepts or, as Toby illustrated, the Japanese bipolar $k a^{\prime} i$ model of international relations, ideas which recall the Roman concept of ager Romanus vs. ager hosticus or the muslim world dar el-harb concept. See R.P. ToBY, State and Diplomacy in Early Modern Japan: Asia in the Development of the ToKugawa Bakufu (1984).

12 Treaty of Wanghsia 1844 (China-US); Treaty of Whampou 1844 (China-France).

13 G. F. von Martens, Précis du Droit des Gens Modernes de L' Europe (1788). 
change and progress. In 1877 China opened a first permanent diplomatic mission in London. Even so, up to 1900, assimilation to Western ideas remained controversial.

\section{B. Korea}

Its reputation of 'Hermit Kingdom' duly testifies to Korea's long-standing official policy of obstinate seclusion. Clearly, early Western gunboat diplomacy had left its mark on the Chosun mind. In spite of protestations from Asian and Western powers alike, the Korean king and ruling yangban class rigidly stood by their steadfast opposition towards reform and infiltration by modernity. As late as 1871 this policy was inscribed in stone slabs, aere perennius so to speak. Still, a mere five years later, in 1876, the administration was forced to give in to Japanese menace and intimidation. Response was lukewarm at first. Yet, waking up to realities, by the mid-1880s emperor Kojong had second thoughts and, if reluctantly, yielded to the opening of diplomatic relations and the conclusion of treaties of friendship and commerce with Western powers. Hence, Korea availed itself of European advisers to invoke Western legal concepts in its diplomatic skirmishes with the US and UK. It opened a first diplomatic mission in Washington in 1887. Even so, the sport of influences from China, Japan, and Russia, its stand in the international arena was vacillating up to The Hague Conferences.

This is not to say that Korean society never came up with an intelligent, pragmatic answer to the dilemma of preserving identity while welcoming modernity. Indeed, from 1876 onwards, when Japan first forced its entrance, within enlightened circles this inquiry was seen as inevitable. Exposure to Japan's alternative approach to modernity prompted calls for reform of the nation's backwardness and military vulnerability. As early as 1879 the Enlightenment Party called for the reception of Western (legal) norms as premisse to durable independence. Kept dangling by Court and administration its leaders in 1884 took refuge in a coup d' état which failed miserably.

A full decade passed before, during the Sino-Japanese War, reforms in the public and private spheres were imposed by the Japanese, the abolition of private slavery featuring high among these. A pro-Japanese cabinet curtailed emperor Kojong' $\mathrm{s}$ executive powers. Right after Shimonoseki, in 1895, new institutional reforms in Western tenor were implemented and a law school opened under strict Japanese guidance. In 1896 Kojong revolted against his Japanese overseeers. Taking refuge in the Russian embassy, he unintentionally called in yet another predator, celebrating a Pyrrhic triumph next year with society purged from pro-Japanese elements.

14 H. Wheaton, History of the LaW of Nations in EUROPE AND the Americas (1845).

15 C. J. Bluntschli, Das Moderne Kriegsrecht der Civilisierten Staaten als Rechtsbuch Dargestellt (1872). 
From here, acute political awareness in Korean society, now torn apart by Chinese, Japanese and Russian infiltration, was unstoppable. By 1898, the Independence Club of moderate and extremist reformers, from lack of response to its endless petitions, turned to militant action, mobilized media and organized demonstrations and strikes to underscore its claims of civil rights, advocate its (perhaps somewhat rash) call for popular sovereignty, and insist on the enforcement of just laws on a modern footing while giving heed to traditional Confucian morals. These were the first, brave glimmerings of Korean nationalism, aspiring at domestic reform to discard corruption and at the reception of modern legal concepts to counter imperialism. For all its merits and best intentions, the movement proved helpless in the onslaught that followed.

\section{Japan}

Symptomatic perhaps of an insular power and an archipelagic people, Japan's introduction to Western modernity gave fewer hickups, with hindsight that is and by comparison. Around 1550, the Empire readily opened up to the first Portuguese and Spanish traders and to missionaries like Francis Xavier. Indeed, of its own accord, it dispatched probing missions to Europe. However, by 1640, rightfully suspecting a hidden agenda behind the massive conversion policy of the Catholic powers, the Tokugawa administration had second thoughts and, expelling all missionaries, in turn withdrew into its cocon. For a full two centuries, its tiny, isolated trading post with the Dutch $^{16}$ on Decima island and intermittent diplomatic contacts with Russia seemed by and large its only loophole towards the West. Overtures from the US in the late 1840s to accommodate its whaling fleet and facilitate trade with the newly opened Californias were kept at bay.

However, when in 1853 the message was brought home at gunpoint by US Commodore Perry's blackships, the lesson was promptly taken to heart. Squarely facing political realities, within a matter of years (1854-56) treaties of peace and amity were concluded with the US, UK, Russia and the Netherlands, and diplomatic missions welcomed into the country. It proved only a first step towards a rapidly expanding treaty network. In the intellectual sphere, Japan displayed a keen appetite for Western thought throughout. Already in 1855 an institute of Western learning was opened.

Still, once the first shock of imperialism was digested and the first wave of modernity swallowed, in Japan too, counter-movements by traditionalists, dissatisfaction over 'unequal' treaties and mistrust of European powers triggered widespread anti-Western sentiment. This increasingly affected domestic politics to

16 Focusing on trade exclusively, the Dutch wisely abstained from religious zelotism. 
finally erode the fragile bipolar system of Mikado and Shogunate. Then, in 1863-64, following riots and the assassination of Western diplomats, bombardments by allied squadrons effectively showed the futility of attemps at expelling the West. This rude awakening sealed the fate of the Shogunate, ensued the Meiji Restoration and invited the proclamation of an official ban on xenophobia.

The crisis proved a catalyst in converting wide-spread resentment over the humiliation as exemplified by the 'unequal' treaties and the embarrassment of apparent racial inferiority and cultural backwardness into a positive drive towards the reception of Western thought and the emulating of 'civilized' norms and modern ways of living. Symptomatic of growing self-confidence was the 1871 Iwakura mission towards Europe and the US. A full hundred scholars and students studied British industry and naval affairs at length, and had their pick of Prussian military discipline, French administration and American agricultural reform.

The Japanese approach to international law went along the same course. As early as 1862, when ordering warships in Holland, Japan sent students in the bargain to study international law at Leiden University. Similar missions invaded Europe, counsel was taken from Western legal experts and international law classics of the period were rendered into the native tongue. Symptomatically, in 1871, Japan concluded a treaty of commerce with China on the basis of sovereign equality along Western modeling. In 1877 Tokyo University was founded. Japan keenly followed developments in codification and humanitarian law, adhered to the Red Cross Conventions and by 1897 boasted an Association of International Law which in 1902 published a journal of its own. Most impressively, to obtain full legal equality with Western nations, in 1890 Japan adopted the 1850, otherwise somewhat backward, Prussian constitution and civil and criminal codes, thus to comply with European criteria for acceptance in the charmed circle. In a matter of two decades, Japanese society was admirably Westernized.

However, no bones about it, in adopting this policy Japan, rather than idolizing the Western world, was spurred by justified fears of the imperialism and gunboat policy to which China had succumbed in the Opium Wars of 1839-42 and 1856-60 and which had undone its social fabric in the Taiping Rebellion (1850-64). To appreciate this, Western legal commentators of the period like Wheaton, Hall or Holland, in their stern positivist approach, never looked upon international law otherwise than as the special treasure of European civilization, to which non-Western nations, neatly differentiated in semicivilized or 'barbarous' and downright 'savage' peoples, might only aspire through a long process of recognition, its reward left at the discretion of the charmed circle, a cooptation system so to speak.17 
More pertinent still, according to these standards, international legal norms were "not held applicable, let alone binding" in the civilized nations' relations with the categories below the salt. In short, Japan' s policy was, if anything, a 'flight forward' to join the charmed circle before falling prey to it. To that extent, the mastery of international law was an instrument, not a goal in itself.

Argus-eyed watching Western meddlings in China and Korea, and finding these too close for comfort, Japan concluded on anticipating on its future status - or should one say decided on proving itself up to par - in venturing upon a similar policy of expansion. In a 'stepping-stone' strategy and starting with the Kuriles Isles in 1875 it mastered the archipelago, by 1890 believing itself historically entitled to and effectively capable of mastering a piece of the pie of the Asian mainland. In a simultaneous process, it stepped up its efforts to topple the Korean administration and ease the country away from under the Chinese sphere of influence.

This campaign was started in 1876 when Japan at gunpoint enforced an 'unequal' treaty on Korea and was concluded in 1894 when, under the slightest of pretexts, it overran the Liaotung peninsula and forced its way into Manchuria. Ironically, a mere matter of days before this campaign was launched, Japan revised its thirty years old 'unequal' treaty with Britain, hence to obtain full equality. Both in terms of right and might it had passed the test. By all standards of the period, it had effectively reached the status of 'civilized' nation.

\section{Outcome}

A concluding note is in order. Since time immemorial, contacts between China, Korea and Japan had been intimate. If not friendly by definition, they suggested continuous exchange, and throughout Japan showed remarkable eagerness in accepting - and dito skill in digesting - superior Chinese civilization. Half a century of meddling by Western powers had uprooted traditions of millennia and unbalanced social fabrics. Bespeaking identity crisis, the three neighbouring peoples were now found jumping at each other' $s$ throats. Indeed, Japan publicly derided reactionary, ignorant Chinese society, and felt pride in its contempt. It presented its 'righteous' war of 1894-95 as an epic fight

17 For a recent overview of these issues see MartTi Koskenniemi, The Gentle Civilizer of Nations; The Rise and Fall of International LaW 1870-1960: Hersch LauterPacht MEMORIal LeCtures (2001); Eyffinger, supra note 1, 5-14 (2007); the same author, A Highly Critical Moment: Role and Record of the 1907 Hague Peace Conference, 54 Neth. InT' L L. Rev. 197-228 (2007). On the Russian tradition, see Vl. Grabar, The History of International LaW in Russia 1647-1917 (1958: English ed. W. F. Butler, 1990); E. Myles, "Humanity", "Civilization" and the "International Community" in the Late Imperial Russian Mirror: Three Ideas "Topical for Our Days", 4 J. His. INT' L L. 310-34 (2002). 
between civilization and barbarism, the historic contest of a culture on the rise with one on the wane - like the Greek contest with Persia or Britain' s struggle with Spain. Rather than being concerned over issues of legitimacy, it seemed committed to political propaganda.

For such strategy there were perhaps grounds. Clearly, Japan was caught in-between two worlds. From fear of giving the Western powers the slightest excuse for intervention it declared itself bound to strictly observe international legal norms. To prove its point, it dispatched international lawyers of repute, professors Nagao Ariga and Sakuye Takahashi, to the front lines, to counsel army and navy and instill upon the world Japan's faithful compliance with international norms - or, as it preferably presented its case, with Western precepts and innate Japanese tradition - as compared to China's total ignorance, perfect indifference and brutal violation of all laws of war, humanity and neutrality. 18

The humiliating 1895 peace treaty of Shimonoseki left China crippled and dealt the dead-blow to the moribund Qing dynasty. The Empire ceded Taiwan to Japan and recognized Korea's formal independence, which in practice implied handing over this sphere of influence to Japan. Japan' s ongoing revision of former 'unequal' treaties with Western powers by contrast, was symptomatic of its new status as major regional power, all set to be welcomed into the charmed circle. However, for all its political efforts and military campaigns, its lip-service to the law and its sycophancy of the West, at the end of the day, Japan found itself tricked out of its most precious spoils of war. By Triple Intervention of Russia, France and Germany - alarmed at finding their vital interests in the region jeopardized by this all too ambitious newcomer - it received 'friendly advice' to evacuate the Liaotung peninsula. Japan, too, had to learn the imperatives of international affairs the hard way.

In this way, in Japan no less than in China and Korea, the seeds of distrust towards the West were laid. Brazenly adding insult to injury, Russia, France and Germany instantly laid claims on all vital ports in the Liaotung Peninsula. In December 1897 a Russian fleet reached Port Arthur, enforcing a lease of this strategic harbour upon China. By 1898, Russia laconically seized the peninsula and extended its Trans-Siberian railway along Mukden to its latest acquisition. To add to Japan's frustrations, the native Taiwan population ran up in arms against Japanese occupying forces. On top of this, its political and military 'reforms' in Korea made that nation turn for help to - Russia, a power only too willing to oblige. On the eve of the First Hague Peace Conference in 1899 Japan had ample food for thought.

18 In subsequent years, these gentlemen, turning to Paris and Cambridge for support, produced impressive treatises, adorned with prefaces by luminaries such as professors Holland and Westlake. 


\title{
III. The First Hague Peace Conference
}

\author{
At the 1899 Conference the Asian world was represented by China and Japan, Siam,19 \\ Persia20 and Turkey.21 By general appraisal their delegations lent an exotic and \\ distinctly 'global' flavour to the assembly. For one thing, they outshone all European
}

19 The Siamese delegates, Phya Suriya Nuvatr and Phya Visuddha Suriya Skdi, their nation's ministers at Paris and London respectively, did not much intervene in the debate. However, the Siamese government had wisely made sure to avail itself of two Western advisers, Corragioni d' Orelli, a prominent Swiss lawyer and diplomat; and no one less than the young but eminent Edouard Rolin-Jacquemyns, Siamese Consul-General in Belgium and the son of the celebrated Gustave Rolin, who had been co-founder of the Revue de drot international (1867) and of the Institut de droit international (1874), and who himself likewise served as counsel to the Siamese government during 1892-1902. Edouard was later to follow in his father's footsteps as Belgian Minister of the Interior, was to serve the League of Nations in various capacities, and became a member of the PCA and the bench of the PCIJ in The Hague. In 1899 Edouard Rolin played an important role as Reporter to the Second Commission's second subcommission and distinguished himself in the debate on land and maritime warfare, on the international missions of inquiry, and on the proposed court of arbitration. In short, the Siamese had an impeccable hand at picking their counsel: their attaché was the later Dutch minister of foreign affairs J.A.N. Patijn. Still, while making sure their interests were excellently served, their native contribution to the debate was perhaps less impressive. Siam signed all six conventions. See Eyffinger supra note 1 185-6 (1999).

20 Persia, expressing the voice and vote of the Near-Asian world, was represented, first and foremost, by General Mirza Riza Khan, an exotic figure of a man with a thick black mustache and sparkling eyes, dressed in a lavishly decorated impeccable white uniform. Fo all this display of oriental wealth, he struck as an enlightened, altogether modern and westernized man. He truly impressed Western delegates as a polyglot. Apart from Persian, Turkish and Arabic he spoke French, German, Russian and Swedish fluently and had a smattering of English "as a kind of garnishing to complete the feast of languages." After the Conference he published a gem of a leather-bound booklet, Echoes de la Conférence, in which he voiced messages of peace in verse and prose in fifteen languages. In Louvain (Belgium), a bust was made in his honour. He sincerely intended to bridge cultural gaps and was known to have tried to introduce the Latin alphabet into Persia, facing strong opposition from the imams. His nation's minister at St. Petersburg, his admiration for the Czar was boundless, much to the amusement of more critical Western delegates. Riza Khan proposed to have hospital ships in his part of the world carry a white flag with a red sun, not - as he elaborated - to rebuke the Swiss, but from fear of the inquietude the red cross would excite in the Musulman army. Besides, he spoke up expertly and eloquently on matters of expanding bullets and other issues of land and maritime warfare. Persia signed all six Conventions. Riza Khan's colleague Mirza Samad Khan, and the delegation's secretaries Samuel de Puliakoff and Baron de Levi left no impression on record. See Eyffinger supra note 1, 170-1 (1999).

21 As stipulated above, Turkey should perhaps best be seen as a trait d union between the West and the East, not a purely Asian nation, to that extent perhaps somewhat identical to Russia, and therefore not quite essential to the core of our debate. So much for certain, the delegation of the Sublime Porte at The Hague, for all its dignified appearance, courteous manners, elegance and impeccable French, never made an altogether favourable impression. It consisted of Turkhan Pasha, Mehemed Noury Bey, Youssouf Bey, Abdullah Pasha and Mehemed Pasha. (For biographical details see Eyffinger 1999 at 193-94). It represented the stringently conservative and military outlook on society. The delegation was unequivocal in its defence of the persecution of the Armenians and averse from all yielding to the Young Turks, whose fierce protests in The Hague caused the delegation considerable embarrassment and only enhanced its defensive tenor. First delegate Turkhan 
delegates by their colourful appearances and dress.22 By the same token, their substantial contribution at this, for most of them, 'entrée dans le monde,' was of necessity limited. The more so as, regrettably, they never spoke with one voice so as to trumpet their continent' $\mathrm{s}$ shared aspirations.

\section{A. China}

The Chinese first delegate, Yang Yü, ${ }^{23}$ while invariably smiling affably, never uttered a single word in public during the full three months. ${ }^{24} \mathrm{~A}$ poet and scholar of exquisite manners and excellent military training, Yang Yü had neither command of English or French. After the ceremonial opening he was rarely seen, preferring meditative strolls along the beach and otherwise "going his way placidly, after the manner of his race." 25 Still, Yang Yü was never fooled by the debate. At one stage, descending the steps of the Huis ten Bosch, he sadly shook his head, smiling: "Too much talkee-talkee, too little doee-doee." ${ }^{26}$ After a debate on mediation he mischievously observed that mediation was one thing but the excessive compensation great powers demanded for their services yet another, a clear reference to the claims the Tripole Alliance forwarded in 1895 for holding the Japanese at bay. Services which had been cashed by the way of Chinese harbours and territory. 27

Pasha, for all his striking appearance and distinguished looks, was a reactionary diplomat, who rarely spoke up in public, allegedly from lack of authority and proper instructions. Accordingly, at The Hague in 1899, Turkey never showed any initiative. To sum up its position: it showed itself adamantly opposed to obligatory arbitration, expressed considerable reserve towards the PCA, never believed in the limitation of armaments, yet argued explicitly against the use of expanding bullets. Various western commentators showed themselves particularly annoyed at the slightly satirical tone and unmistakable irony noticeable with Turkish delegates or, as Baroness Von Suttner remarked at one stage: "Both the Ottoman dignitaries give me the impression of not regarding the success of the business here as especially likely or desirable." Turkey made reservations to Convention I (Pacific Settlement of Disputes) and Convention III ( 'Geneva' Convention).

22 Witness Baroness Von Suttner: "The Chinaman and his wife again make the most striking appearance in this circle. They are in silken robes with rich embroidery of flowers, but Mrs. Yang wears for the adornment of her head only the usual paper flowers hanging down over her temples." See Eyffinger supra note 1, 138 (1999).

23 Yang Yü(1841) was a mandarin of the second rank wearing the peacock feather. He was a diplomat educated at Beijing, formerly accredited to Washington, Lima and Madrid and at the time plenipotentiary minister in St. Petersburg and Vienna.

24 Hoo-Wei-Tei; Lou Cheng-Chiang, Ho Yen Chiang and counselor and interpreter Dr. Kreyer. For biographical details see Eyffinger, $i d$.

25 Id. at 137. (Quoted from the British journalist Stead).

26 Id. (Quoted from the American delegate Holls).

27 In a letter from Stead to Czar Nicholas it reads: "Yang Yü, the Chinese delegate, has at last expressed an opinion, and a grimly humorous one it is. He proposes to add to the Article on Mediation, which ends by declaring that the offer of mediation shall not be regarded as an act 'peu amicale' the further proviso that Mediation shall neither be held to justify the mediating Powers in making excessive demands for compensation for their services. Poor Yang Yü ruefully remembers the price China had to pay for the 
Lou Cheng-Chiang intimated to Baroness Von Suttner that China welcomed disarmament, inasmuch as "we are particularly threatened by the most serious dangers of the european policy of force." 28 In his closing address to the Plenary on behalf of Yang Yü he declared that China had maintained a constructive approach throughout and readily complied with all humanitarian propositions. As Stead sadly commented: here are three men, representing one third of humanity, Confucians who live quietly together without so much as a standing army. We Christians, about the same number, need five million soldiers to barely keep us from slicing each others' throats, yet insist on instilling our clashing convictions upon mankind. ${ }^{29}$ China signed all conventions except the one on the Laws and Customs of War (Convention II).

\section{B. Japan}

Not surprisingly, intellectually the most impressive delegation to represent Asia was Japan. It was the most powerful, best schooled and most acutely interested Asian power. Whereas the Chinese delegation regarded her presence as more or less complimentary, the Japanese, while pragmatic as ever, radiated from first to last their keen awareness of their importance and ensuing responsibilities. Typically, its delegates and spouses were impeccably dressed along the latest line of European fashion. In spite of growing Western concerns over its military tenor, enthusiasm for the Conference in Japan was widespread and sincere, including the disarmament and arbitration paragraphs. 30

Japan's first delegate, Baron Hayashi, epitomized his generation's approach to society. He had travelled extensively, had been vice-minister for foreign affairs during the Sino-Japanese War, supervised the execution of the Shimonoseki peace terms and, in his capacity as ambassador to Russia, personally attended the launching of the Rescript. His acute views on the world of diplomacy are attested in the levelheaded observations on humanitarian issues 31 and Russia' s position in the East 32 in his memoirs of the Conference.

mediation of Russia, Germany and France at the close of the Japanese War. Id.

28 Id. at 138. Lou Cheng-Chiang was later to become plenipotentiary minister in The Hague and attended the 1907 Conference as second delegate.

29 Id. at 137.

30 Among the hundreds of petitions from all over the world entered in the Dutch national archives are entries from the Japanese Women International Peace Association.

31 "[W]hile accepting the sinking of a battle-ship with hundreds of its crew members losing their lives suffocated at the bottom of the sea, or the detonating of land mines, thereby killing hundreds of people at one time, it was decided that the use of paralyzing gas as a weapon to incapacitate the enemy force should be prohibited on the ground that it is against humanity. You should guess the rest of it..." Id. at 161.

32 "At the time of the Peace Conference, Great Britain had to prepare itself for a precarious situation in South 
To illustrate that Japan came well-prepared: its military expert was Nagao Ariga himself. 33 Ariga made several to-the-point interventions on issues of land warfare. He was escorted by a hero from the 1894-95 campaign, the later field-marshall YUSKA Uyehara. Japan's naval expert, Toshihatsu Sakamoto, never schewed debate either. Regarding drop armaments limitation armaments he insisted in no uncertain terms on close inspection so as to verify that pledges officially taken were effectively kept.

Still, the most impressive Japanese debater was Ichiro Motono, second plenipotentiary delegate and later Foreign Minister, who left a distinct mark on the Conference. A specialist on maritime war and the Geneva Conventions, he maintained that merchant ships that happened to carry a few hundred wounded should not on this title alone escape capture. 34 Likewise, as against Louis Renault, he insisted on the Japanese custom not all too rashly lend the status of a Red Cross Society relief ship to all yachts and boats equiped by private individuals. 35 Another sensible and pragmatic observation of his was that if the 1864 Geneva Convention on Land Warfare also applied to landed seamen who were transported by ambulance, the same should apply in its mirror-Convention on Sea Warfare for the military transported by hospital ships. 36

Finally, he wondered whether the reading that repatriated prisoners were not entitled to serve anymore during the war should be interpreted as serving as soldiers or tout court, in whatever capacity. $37 \mathrm{He}$ acutely noticed inconsistencies between the Land and Sea Warfare Conventions regarding the status of sick and wounded, earmarked as neutrals in the one and as prisoners-of-war in the other-which was manifestly disadvanageous to Japan. 38 The above observations were very pertinent to the RussoJapanese War and inevitably resumed in 1907.39 By 1899, alone within the Asian commonwealth, Japanese lawyers were a fair match to their Western counterparts.

Africa. On the other hand, Russia was about to set off along lines of policy which could not have had any consequences other than a serious confrontation with its neighbouring countries in the East." Id.

33 Nagao Ariga was Japan's legal counsel in the 1894-95 Sino-Japanese War, and author of authoritative monographs on the subject. He was, so to speak, midway his career. In years to come, he would play an identical role, both as counsel and author, in the Russo-Japanese War. He was fluent in English, German and French.

34 See Scott supra note 1, at 453.

35 Id. at $458-59$.

36 The 1864 Geneva Convention art. 8. See Scott id. at 463. Motono made observations of similar purport with regard to Articles 2 and 7 of the 1864 Geneva Convention.

37 Id. art. 9. See Scott supra note 1, at 464.

$38 \quad$ Id. at 468.

39 In October 1900 Japan deposited its signatures and by February 1901 had ratified the six Conventions. Ichiro Motono and Denison were registered in the list as membres of the Permanent Court of Arbitration in The Hague. 


\section{The Interval}

\section{A. The Boxer Rebellion}

Within months after the Conference, with South-African Boers running up in arms against British meddling, slumbering xenophobia among peasants in northern China erupted in the Boxer Rebellion. Revolt was triggered by the 'Hundred Days Reform' proclaimed by the Qing dynasty, never too popular under the best of circumstances on behalf of its 'foreign' background and its failure to curb Western imperialism. In June 1900 the Boxers marched upon Beijing, leaving deep marks of violence wherever they went. Along the way they burned the detested Russian railway stations and massacred Christians by the thousands. With central government paralyzed and gradually giving in to the rebellion, foreign legations hurriedly barricaded the Legation Quarter. Matters escalated when the German embassy was stormed and its envoy lynched. With the legations demanding redress, Empress Dowager Cixi declared war on all Western powers, provoking global anti-Chinese sentiment. Holding out a 55 days siege, the legations were relieved by an Eight-Nation Alliance of 50.000 headed by Japan, Russia and the UK. Punitive expeditions and retaliation followed.

\section{B. A Diplomatic Revolution}

The impact of the Rebellion was immense. In China Western reforms were quickly taken to hand and proved unstoppable. Even so, revolt and awakening nationalism never died, to seal the fate of the Empire. International repercussions were no less consequential. Japan's prominence in quenching rebellion received symbolic reward in its recognition by Western powers as a modern, civilized power. However, to the consternation of Japan and the UK, that other naval power with vested interests in an 'open door policy' in the region, Russia in October 1900, allegedly in retaliation to China, brazenly occupied northern Manchuria.

Whereas, up to then, Britain had held firm to its time-honoured policy of splendid isolation, as testified by its refusal to enter into the 1895 Triple Intervention against Japan, overtures were now seriously contemplated. With lukewarm Russo-Japanese diplomacy to reach a compromise ending in deadlock, on January 30, 1902 Lord Lansdowne and minister Tadasu, after six months of deliberations and overcoming their differences over Korea and India, signed a momentous Anglo-Japanese Alliance40

40 For details, see Ian H. Nish, The Anglo-Japanese Aludance: The Diplomacy of Two Island EmpiRes 1894- 
which, in Article 3, promised reciprocal support when either signatory became involved in war with more than one power.

The Alliance stands out as a milestone in British diplomacy in ending the Era of Isolation. But to Japan the moment was no less historic. Even if, in March 1902, Russia signed an alliance on similar terms with France, ${ }^{41}$ Japan felt satisfied that, when put to the test, France would never risk war with Britain. 42 The overarching meaning of the 1902 Alliance to world politics was that, with Russo-Japanese antagonism in the Far East irreconcilable, it facilitated war conditions. Japan had successfully wiggled its way into the powerplay and fulfilled all premisses to defy a vested world power. The outcome was to stun the world.

However, ever before war started, the combination of the Anglo-Japanese and Franco-Russian alliances generated a diplomatic impetus of its own. For fear of being dragged into the conflict on different sides, Britain and France, nations that could not exactly pride themselves of a record of understanding in European or colonial matters over the two preceding centuries, buried the battle-axe. In the unprecedented Entente Cordiale of April 1904 they agreed to abstain from interfering in the eventuality of conflict in the Far East. 43 Britain was lured into the lion's den of continental politics. In France, finding the world's foremost naval power on its side had the same psychological effect as the 1902 Alliance had on Japan. Both nations felt encouraged to (over)confidently challenge their opponents, Russia and Germany respectively. The outcome was, here, the Russo-Japanese War, there, La Grande Guerre.

\section{The Russo-Japanese War}

Up to 1904, throughout its fruitless negotiations with Russia, Japan's policy had been aimed at abandoning Manchuria in exchange for control over Korea. Unwilling to provoke British rancour, Russia's Count Witte, by August 1903, felt inclined to give heed to the British hint implied in its alliance with Japan and acquiesce in evacuating Korea. At that juncture he was routed by Czarist jingoists, who intensified their grip on Korea. By Fall 1903, and in spite of active French mediation by Delcassé, talks between Russia and Japan failed utterly. By that time Japan, adroitly posing as champion of Asia

41 Germany, interestingly, declined the invitation.

42 The calculation was impeccably correct in military terms. As it is, France financed half of the Russian campaign, at enormous costs.

43 They also came to terms with regard to their long-standing differences over Egypt and Morocco, Siam and Madagascar. This triggered the Morocco-crisis of 1905, provoked by Germany and appeased by the Algeciras Conference, early in 1906, which sealed Germany's isolation, with dramatic results. 
against Russian aggression,44 had managed to rally Korean public opinion and secure itself of that nation's support in exchange of its promise of Korean independence once Russia was routed. Henceforth Japan, to all intents and purposes, gambled on war. On February 6, 1904, it recalled its ambassador from St. Petersburg and severed diplomatic relations. Two days later, to the horror of the world and without formal declaration of war, Admiral Togo, by a nightly torpedo boat raid, sank part of the Russian Far East Fleet in Port Arthur. Wrongfooted and on the defence from the first, Russia never regained the upper hand in the war. 45

It was the first major clash in the Age of Technology. Its massive onslaught overnight turned tables of geo-politics. Machine guns mauled down human waves of infantry in harsh winter trench war. Huge navy crews fell prey to treacherous torpedoes and floating contact mines.46 In recognition of success, a full century after Trafalgar (1805), a lock of admiral Nelson's hair was presented to Tokyo. Britain, ironically, felt pride in having set Japan on its course of four decades towards domination - and doom. Our main concern are the war's legal implications, which constituted the piéce de résistance of the 1907 Hague debate. We will best discuss these issues from that perspective and in that context.

\section{D. 'The Hague' Revived}

Meanwhile, in Washington, President Theodore Roosevelt, not otherwise known for his pacifism by conviction, had gratified the appeal of the Interparliamentary Union 47 to reboost The Hague Peace Tradition. The initiative was another sign of the rapidly changing tide, the rise of the New World, vibrant American internationalism and Roosevelt's growing prestige.48 On October 21, 1904 Secretary of State Hay sent

44 Indeed in much the same way as the US in the Latin-American region.

45 Subsequent major military facts of this stunning war are well-known: the naval battle in the Yellow Sea in August 1904; the long siege and fall of Port Arthur in January 1905; the decisive military battle at Mukden in February 1905; the decisive naval battle at Tsushima Strait in May 1905.

46 An estimated 150.000 casualties prefigured the horrors of WW I.

47 In the summer of 1904 hundreds of parliamentarians and peace activists first crossed the ocean on the occasion of the 1904 St. Louis world fair. At their meeting in St. Louis a Resolution was passed to invite President Roosevelt to initiate a Second Hague Conference. The Resolution was personally handed in at the White House.

48 In 1902 Roosevelt had adroitly rekindled the moribund Pan-American Movement. Subsequently, he had further ingratiated the Latin-American world by helping submit Venezuela's dispute with European powers over outstanding loans, which had led to bombardments and blockades by a German, English and Italian flotilla, to the struggling Permanent Court of Arbitration in The Hague, the boast of the 1899 Peace Conference. By 1904 he was looked upon by the region as its best bet to preclude the European Powers' 'Scramble for the Americas.' The 1902 blockade of Venezuelan ports by German, British and Italian warships, the subsequent seizure of its fleet and bombardment of coastal townships served as an interesting 
invitations for a Peace Conference to all signatories of the 1899 Conventions, making sure to include the Latin-American republics 'by anticipation.' By the irony of fate, the letters were dispatched in the very night of the Dogger Bank Incident. As it happened, Admiral Rozhestvensky's Russian Baltic Fleet, on its way to the war theatre in the Pacific, having received warning of Japanese naval presence in the Atlantic, in the pit of night, off the coast of Hull, sadly mistook British trawlers for enemy vessels, thereby sinking innocent fishermen and creating a diplomatic incident with the UK. The succesfull factual inquiry by an international board of admirals under the auspices of the PCA appeased parties, thus to give an unprecedented boost to The Hague Court and its mechanism of pacific dispute settlement.

\section{Preliminary Skirmishes}

\section{A. The Russian Prerogative}

Affronted for having been bereft of what it considered its prerogative on the Peace Conference, and anticipating that 'The Hague' would most likely condemn its war policy, Russia urged for postponement. Japan, on its part, rightly anticipating Russian obstruction, adroitly made no such objections on principle, merely arguing that war topicalities were better abandoned at The Hague. In subsequent months Russia turned down Roosevelt's offer to orchestrate peace talks in The Hague. Deluded by hope of turning the war momentum, Russia declined all peace propositions until growing internal unrest after the staggering losses at Mukden and Thushima Straits -

test-case for Far Eastern nations to appreciate the policies of imperialism. The incident had an incisive impact on interstate relations and repercussions throughout the New World. In December 1902, Argentine's Foreign-Minster Drago voiced the concern of the Latin-American region in his famous Drago-Doctrine. In his view, the obligation of payment of public debts was never contested. In the case of Venezuela, however, and owing to revolution and social change, the debtor country seemed entitled to at least some latitude in paying instalments before being incriminated of bad faith and deliberate insolvency - and face downright war. Jeopardizing stability and peace on the American Continent, the actions of the allied powers were seen as blatant infringement of the 1823 Monroe-doctrine and the more than likely forebode of a 'Scramble for the Americas' under the veil of financial intervention. In 1904, pursuant to Drago' s doctrine, Roosevelt formulated his famous Monroe Corrollary and 'Big Stick' policy. The 1906 Third Pan-American Conference in Rio, appreciative of diverging doctrine and ambiguous international practice, recommended submittance of the issue to the 1907 Hague Conference. Honest debtors should be protected from military intervention, honest creditors from feigned insolvency. The outcome, notably thanks to US insistence, was the 1907 Convention on the Limitation of the Employment of Force for the Recovery of Contract Debts [Convention II].

49 The US complied with the Japanese Protectorate in exchange for Japanese support to US policy in the Philippines. Similar considerations prevailed with the European nations. 
culminating in peasants' bread revolts like Bloody Sunday - forced it to give in.

On September 5, 1905, through Roosevelt's mediation, in Portsmouth (NH) Russia signed the humiliating peace terms which stipulated its evacuation of Manchuria and its acquiescence, given US and UK compliance, ${ }^{49}$ with Japan's protectorate over Korea. With hindsight this was the critical moment for Korea. Its army and navy helpless to the modern powers, divided by ten years of subversive infiltration from three sides, paralyzed by corruption, the ancient, proud nation, headed by an ageing emperor, was victimized to the powerplay of the great.

Undaunted, within a week after Portsmouth, Russian ambassador Baron Rosen in Washington brazenly informed Roosevelt that the Czar now felt in the position to resume The Hague initiative, a request Roosevelt courteously obliged with.50 To Russia, the Conference served above all to regain international prestige and distract attention from its troubled domestic horizons. Meanwhile, its former perspective had changed dramatically. In 1898 it insisted on peace and disarmament to gain time. In 1906, keen to reform its military and rebuild its fleet, it excluded disarmament as a matter of principle.

\section{B. The Disarmament Issue}

In this policy it was warmly supported by Germany. Having put the Anglo-French Entente to the test by forcing crisis over Morocco, early in 1906, at Algeciaras, its scheme had backfired, leaving Europe's most formidable military power out in the cold, the sport of frustrations, social scandals, and fears of encirclement by Russia, France, and Britain. Henceforth, all German considerable energy was devoted to its impressive fleet programme and heavy military build-up.

In London, by contradistinction, the exhaustive Boer Wars, which had pushed the Empire' s resources to the limit, had neatly appeased Jingoism. In a political earthquake, a Liberal cabinet had taken over, determined on peace in the best of Gladstonian traditions. It advocated arbitration and cut down the Dreadnought programme 51 to generate funds for social legislation and pension plans. In another historic move inspired by the scutcheon of its new alliances, it abandoned its legendary double strike naval policy, viewing Germany as the only naval opponent left. Only thanks to the competent shuttle diplomacy of the Czar's foremost counsel and founding father of The Hague Tradition, Feodor Martens, the Conference was not smothered in the cradle by

50 As it was, the Conference had to be postponed to 1907, due to the prior engagements of nations at the PanAmerican Conference and the Conference for Revision of the Red Cross Convention in Geneva, both scheduled for the summer of 1906.

51 This 'all big-gun' ship was first launched in 1906 and was the British equivalent of Japan's Satsuma (1904). 
Anglo-German antagonism, and a workable formula found in a 'burial first class' (as it was cynically called at the time) of the disarmament paragraph, thus leaving latitude to both sides to duly charm their electorates. The Hague 1907 was to be a War Conference.

\section{Japanese Resentment}

Japan, by 1906, was not a happy place, either. It felt that, whereas the war had been gloriously won, the peace had been ignominiously lost. Once more, Japan felt tricked out of Manchuria, this time by American stratagems. Resentment grew high and riots were the order of the day. Dissatisfaction was not tempered by the outcome of Japan's first case at The Hague Court. On the contrary, the so-called Japanese House Tax case 52 tore open old sores. Japan had been among the most ardent advocates of the PCA in 1899, had been keen to submit a dispute, if only to establish a record in The Hague, and felt satisfied in anticipating its favourable outcome.53 The award on May 22, 1905 in favour of the Western claims promptly drew anti-foreign sentiment and allegations of racial discrimination.

Cornered by malcontents from all quarters, the Japanese administration, to appease public opinion and again with tacit American and British approval, countered by speeding up infiltration of Korea. On 17 November 1905, the Korean Emperor and administration were pressed at gunpoint to accept the terms of the so-called Protectorate Treaty, which finished Korea's control over foreign policy, if not its independence. In order to colonized the country, Japan 'reorganized' its currency and

52 See A. M. Stuyt, Survey of INTERnational arbitration 1794-1970 RIAA XI-47 (1990: Survey No. 247 ); M. O. Hudson, The Permanent Court of International Justice 1920-1942, A Treatise 16-7 (1972, reprint ed.); P. Hamilton The Permanent Court of Arbitration: International Arbitration and Dispute Resolution; Summaries of Awards, SeTtlement Agreements AND Reports 38-41 (1999). The Japanese House Tax case was submitted to the PCA on August 28, 1902 by compromis between Japan and three Western powers: Germany, France and the UK. The panel consisted of Mr. Itchiro Motono (1899 delegate) for Japan and French Louis Renault on behalf of the Western Powers, with Gregers Gram from Norway as sur-arbitre. The Japanese agent was Mr. Miyaoka, the Western agent Descamps (Belgium). The arbitration was brimmed with complications. It took parties ages to agree on the choice of languages. The award was rendered on May 22, 1905, after a mere four sessions. Thereupon Mr. Motono, while signing the award, declared to dissent both in terms of reasoning and conslusion. Finally, the president' s closing speech provoked a diplomatic incident. Apart from its substantial merits, the case was of paramount import to the 1907 Conference in prompting various pertinent questions relating to arbitral procedure.

53 The substance of the case drew back to the mid-19th century, when Japan had first opened up its ports and cities to foreign nationals and allotted them lands and buildings in perpetual leases. At the time, foreigners were not entitled to own property in Japan. When abolishing this concession system around 1900, Japan concluded treaties with the Western powers in return. The rather technical issue at stake in this dispute was whether under treaty stipulations only the lands or lands and buildings held under lease were exempt from taxation other than agreed upon in the leases. 
school system, and put up a puppet administration. This circumstance prompted a most embarrassing incident in The Hague. Before addressing the substance of the 1907 Conference, we will first discuss this incident.

\section{The Korean Incident ${ }^{54}$}

\section{A. An Overview}

Korea had not attended the First Hague Peace Conference. Yet, by ratification of 7 February and 17 March 1903 respectively it had adhered to The Hague Convention on War on Land [Convention II] and its 'Geneva' Convention [Convention III]. In this way, it became a Member of The Hague Conference. On this title, on 25 September 1905, and whether or not as a political stratagem on the part of Russia, 55 it had received a formal invitation from St. Petersburg to attend the Second Conference. Emperor Kojong proceeded to appoint a delegation of three when, mid-November, by virtue of the socalled Protectorate Treaty of 1905, he was forced to abandon foreign policy and was put under house arrest. Meanwhile, his secret envoys were on their way to The Hague via Vladivostok. They made it on the Trans-Siberian railway to St. Petersburg and, after a heroic journey of a full two months, armed with letters of credentials, found lodgings in The Hague. 56 The delegation consisted of three envoys: firstly, the former vice-premier Yi Sang-Sol who, having resigned his position, had become a prominent spokesman of the national resistance movement; secondly, the former judge of the Supreme Court Yi Jun, a pious Christian who had resigned as preliminary judge of the Supreme Court in protest of the 1905 Protectorate Treaty; and, thirdly Yi Wie-Jong, a young diplomat and the official spokesman. 57

On 30 June, 1907, to the embarrassment of the world, the delegation presented its credentials to the Russian President of the Conference, who did not react.58 On July 1, Yi

54 See Eyffinger supra note 1, 145-9 (2007); S Murase, The Presence of Asia at the 1907 Hague Conference, Colloquium of The Hague Academy of International Law, 6-7 Sept. 2007 [forthcoming 2008] ; A. Eyffinger, Yi Jun, Icon of the 'Hague Tradition'; The Pertinence of Korea to the Second Hague Peace Conference, Proceedings Commemorative Colloquium Yi Jun Museum Jul. 2007 [forthcoming 2008].

55 By stipulation of the Portsmouth Peace Treaty, Russia had acquiesced in the independence of Korea, whatever interpretation Japan might give to this.

56 In the modest Hotel De Jong at Wagenstraat 124, the current location of the Yi Jun Peace Museum.

57 He had enjoyed a consummate education in the US where his father had been plenipotentiary and had been trained at St. Cyr military academy in Paris. He held diplomatic posts at Paris and St. Petersburg and had a Russian aristocratic spouse. Hence, in The Hague, he was mostly called 'Prince Yi.' 
Wie-Jong requested an interview with Dutch Foreign Minister Tets van Goudriaan. From the internal correspondence of the Foreign Ministry one must conclude upon the Dutch position that, as the 1905 Protectorate Treaty bore the signature of the Korean Emperor, whatever else might be said of it, it had to be acknowledged as representing Korea's official position. Worthwhile to fully appreciate Dutch interests is an obiter dictum by then the Foreign Minister De Beaufort in his Diary of 13 August 1904:

"I have always hoped that Russia would destroy Japan completely. Since this has not been the case, I wonder whether it would not be ever better for us to have Japan occupy Korea and Manchuria. Otherwise, sooner or later, its eye may well fall on our Indian Archipelago. At all events, we must take care to remain on the best of terms with Japan." 59

It is a sobering statement. Korea, by the appraisal of the contenders, had overplayed its hand. De Nelidov told De Beaufort point-blank that Russia was in no position nor indeed willing to help a country that had relied on Japan in its contest with Russia. 60 Japanese first delegate Tsudzuki told De Beaufort that Korea had all too long tried to play off Japan and Russia. 61 This censure clearly overstretched Korea's options in the face of its two formidable opponents. ${ }^{62}$ On 7 July, 1907 Tets van Goudriaan pointed out to Yi Wie-Jong that Russia was responsible for the invitation policy but that the Dutch saw no grounds for questioning the 1905 Protectorate treaty.63 Tension ran high. Japan

58 The delegation then contacted the American delegate Horace Porter who probably had received timely warning from the Japanese delegation and pretended not to be home. In the end they were received very cordially by the American First Delegate Choate, who told them frankly that he could not give them much hope. Other delegations volunteered much similar replies.

59 See J. P. De Valk \& M. van FaAssen eds., Dagboeken en aAntekeningen van Willem Hendrik de Beaufort 1874-1918 [RGP Kleine Serie nos. 73-74], 2 vols. (1993). Quote in vol. I at 262. Upon their arrival, the Korean delegates had also sent their visiting cards to De Beaufort. He went to pay them a visit at what he called "een koffiehuis met logement van den vierden rang" [a coffeeshop with lodgings of the fourth class] where he was received by a lady of "not all too puritan outlook."

60 Also, the new Russian foreign minister Izvolsky favoured a conciliatory policy towards Japan, acquiescing in its protectorate of Korea in exchange for Japan's recognition of Russia's special interests in Manchuria. Actually, an agreement to that purport was reached those very days, on July 3, 1907. See Murase supra note 54.

61 On 18 July, over dinner at the Japanese Embassy. See De BEAUfort Dagboeken I at 390.

62 As De Beaufort acutely observed, Korea' s position was like that of Bavaria in 1870, which all too long stuck to its fruitless opposition to an alliance with Prussia.

63 De Beaufort in his Dagboeken voiced his impression of Prince Yi, who struck him as more Chinese- than Japanese-like in outer appearance and impressed him favourably by his impeccable French. (it is recalled that Prince Yi had been trained at the Military Academy of St. Cyr in France). Like De Nelidov, De Beaufort questioned the authenticity of the Delegation's credentials, yet was favourably struck by the delegates who did not gave him the impression "of being imposters." Id. at 384-5. 
kept contesting the status of the Korean delegation and the authenticity of its credentials, while the Korean delegation kept protesting the illegitimacy of the 1905 Protectorate treaty. The incident kept Tsudzuki preoccupied to the point of preventing him from attending the Conference at all.

Frankly speaking, the issue could not reasonably be raised at the Conference. Precisely to forestall these incidents, the Conference Programme was very stringent and delegates were urged not to have political topicality interfere.64 In spite of all Korean petitions to the nations, in the official sphere the incident rested here - in The Hague that is. In Korea, repercussions were immediate and dramatic. Japan insisted that the Korean emperor repudiate his delegation and sentence Yi Wie-Jong to death by hanging. Subsequently, it ordered the Korean emperor to abdicate. 65 Kojong effectively resigned on 19 July, whereupon the Japanese foreign minister Baron Hayashi - Japan's first delegate to the 1899 Peace Conference - in an agreement signed on July 24 began to annex Korea. Thus, in Korea, the incident served as catalyst to speed up Japanese infiltration and conquest, a process formally concluded in 1910.

\section{B. Stead' s Interference ${ }^{66}$}

The official deadlock would have been the end of the matter in The Hague, if not for the flamboyant British journalist and peace activist William Stead, editor of a Conference Daily, Le Courrier de la Conférence de la Paix.67 Stead was not the type of man to leave the matter untouched. He commented on the delegation's mission on 5 July, 1907, presenting a picture of the delegates on the front page of the Courrier along with an interview with 'Prince Yi.' 68 The 'interview' was just another magisterial move on

64 To that extent, too, delegates in 1907 were the wiser from earlier experience in 1899. At the time, with the Boer Republics, colonists from Dutch descent mostly, on the verge of war with Britain, anti-British demonstrations in The Hague had been frequent. Likewise, the presence of Bulgaria, which in 1899 was in a similar position to Turkey as Korea was to Japan in 1907, was heavily contested. It is interesting to note that, in 1907, the parallel between the relation Turkey/Bulgaria and Japan/Korea, obvious to William Stead, was never drawn to the attention of diplomats [see infra note 69]. In 1907, as before, numerous were the political movements like socialism and anarchism who were only too keen to wreck the Conference on the cliffs of political controversy. Like the Korean delegation, Zionists had come over to The Hague to energetically plead their cause for a nation-state of their own.

65 See Davis supra note 1, at 194.

66 On William Stead' s dealings with the 1907 Conference see Eyffinger supra note 1, at 141-9, and W. T STEAD, Courrier de la ConfÉrence de la PAIX (1907); Le PARLEMENT de L' Humanité (1907).

67 Stead's headquarters were at the so-called Cercle International, a venue where delegates, pacifists and journalists met on a daily basis to attend lectures, hear the latest, and have a nice little chat.

68 "I have come to The Hague to see with my own eyes the Altar of Law and Justice. Where is this famous Court of Arbitration? And what is the value of treaties after all? Japan has in 1905 solemnly sworn to our independence and political integrity! Now we are prisoners in our own country! How could all this happen? 
Stead's part to put the cat among the pigeons. On 9 July Stead pointed out that the Korean attempt for accession, if in vain, was of the utmost importance: 'Tôt ou tard,' at one stage the Conference was bound to review its invitation policy. 69 That night, Prince Yi gave an emotional address at the Cercle. It must have been quite a night! In his "Plea for Korea" he gave a compelling overview of the way Japan had belied its earlier promises to Korea and, drunk from its astounding victories, had implemented a brutal regime of oppression in Korea.70 The matter took a dramatic turn when, on 14 July, with Prince Yi abroad,71 Yi Jun, the second plenipotentiary, aged 49, was found dead in his hotel room. A seemingly innocent cheek abscess had urged an operation which had

Simply because we are weak and Japan is strong. We have no armies or ambitions of aggression. We just wish to live in peace and quiet. 'Nous pratiquons ce que vous prechez, vous, Pacifistes. Oú en sommes nous maintenant?' [We practice what you preach, you pacifists. Where has that left us now?]. We have an army of 7000 on a population of 20 million. We could have put up resistance in our rugged mountain area like the Swiss once did. But we do not care for aggression." Stead was a formidable journalist.

69 Up to now, Stead argued, Russia and the Netherlands had been like a "father and mother" issuing invitations to their "dinner party." The Third Conference should professionalize this: "De la sorte que les Coréens vivront dans l' histoire comme étant ceux qui, sans le savoir, auront précipité une décision d' importance vitale, qui aura une influence permanente dans la suite sur l' évolution de l' Etat Mondial." [As a consequence the Koreans will live on in history as the ones who, unwittingly perhaps, have accelerated a vital decision of lasting influence on the future development of the World State.]. Stead drew attention to a curious anomaly. The situation of Korea was not different from that of Bulgaria vis-á-vis Turkey. Still, that nation had been invited, in 1899 under Turkish suzerainty and this time even on its own full title. Again, Montenegro was a sovereign State which had volunteered, as in 1899, to have itself represented by Russia, without otherwise as a consequence losing its sovereignty. Korea, by comparison, had against its will and by dint of arms entrusted its foreign affairs to Japan. As a penalty, it was now barred from entering the Knights' Hall. Korea was the only major absentee worldwide. All other States not represented at the Conference were 'small fry' really and, as the Latin saying went: de minimis non curat lex.

70 As Yi recalled, in November 1905 Marquis Ito, a former Japanese minister, had come to Seoul as special envoy of the Mikado. That same month he had wrenched from the Emperor the vexed signature on the 1905 Protectorate Treaty: "Yield, or it means instant destruction to all." Yi vividly portrayed the way Ito had thus, literally at gunpoint, forced the Korean cabinet to comply with his terms; how the ministers had resisted, till one of them gave in; how the Korean people rose in revolt, vainly implored the help of foreign nations, then were quieted by guns. He sketched recent horrifying events, and how suicides of prominent figures all over the country had added dramatic weight to the revolt: Prince Mom had cut his throat; a former minister had written farewell-letters to the foreign nations and to his people and then taken poison; in Seoul the blood had run in rivers through the streets. At last, in revenge to massive expropriations of land-owners, the bankrupting of merchants and cruelties unheard-of perpetrated to women and children, the patriotic Korean people, from sheer disgust and dispair, had vented its fury on "Japanophiles," provoking new rounds of retaliations all around.

71 On 11 July, Prince Yi had left for Russia to meet his father, Chim Pon Ye, former Korean representative to the US and a close relative to the Emperor himself, who now lived in St. Petersburg. Prince Yi' s idea was to try and bolster help for Korea among his contacts at the Imperial Court. As a matter of fact, back in 1905, in reply to Count Lamsdorf s first invitation to Korea to attend the Conference, it was Prince Yi' s father who had been appointed First Delegate by the Emperor. As a consequence of Prince Yi's absence, back in The Hague, the third delegate, Sang-Sol, was the only Korean to assist the unfortunate Yi Jun in his final hours. 
proven fatal.72 The third delegate Yi Sang-Sol was overheard stammering the only words he knew in English: "So sad, so sad..." As Stead commented dramatically: "Even if he had had a perfect command of our language, he could not have expressed more precisely the feelings we all share." 73

On 18 July, Prince Yi returned to The Hague, deeply moved.74 The idea was to have Yi Jun's body carried to Rotterdam, shipped to Shanghai, and from there transported to Chemulpo in Korea. It was not to be. The Japanese were mordically opposed, also because Yi Jun's death had caused severe unrest in Seoul. This unrest made Japanese governor Marquis Ito insist on speeding up annexation and force the Emperor to abdicate. Yi Jun was provisionally buried in The Hague. 75 He has been a national hero and martyr ever since.

\section{The Substance of the Second Hague Peace Conference}

The Second Hague Peace Conference, so much the above has established, was a unique exchange of views at a moment of paramount interest for Asia as well as for Europe. Its debate impeccably touched upon the sore of early 20th century international society. Its failure to reach agreement on all too many vital issues had dramatic consequences: 1907 proved the last stop of the nations on their headlong race to trench war in Flanders. On the spur of blatant imperialism, fervent nationalism and implacable antagonism the

72 In days following, Yi Jun's body was provisionally transported to Nieuw Eijk en Duinen awaiting proper funeral.

73 At the time, speculation of ritual suicide, even murder, did the round in The Hague. In the absence of conclusive documents, this matter is not for us to decide here and now. Suffice to say that Yi Jun, like so many of his compatriots before him, upon his arrival in The Hague had turned to the passive weapon of hunger strike as a token of silent protest; that he must have been exhausted by the exacting trip, was living under severe tension and, as his legendary last words "Save my country!" demonstrate, was clearly a heart-broken man overwhelmed with grief; finally, that the medical report simply stated "death from heart failure."

74 Prince Yi' s report is not without interest: "If a personal loss to me, it is a greater loss to my country; Yi Jun was the kind of patriot each country would be proud of. A patriot and a martyr, for, clearly, he died from grief. He had an iron constitution, but the Japanese atrocities made him lose the willpower to live. He had not taken food for days on end. The abscess itself was insignificant, and at St. Petersburg the news of his death took me wholly by surprise. The last hours before he died he slept very deep, as if unconscious. Then, suddenly, he woke up and with his last breath cried out "Help my country, the Japanese are ruining Korea..."

75 The ceremony took place on 5 September. On the occasion, former Dutch minister Baron Mackay delivered an obituary at the grave. It was not until 1963 that the remains of Yi Jun were carried back to his home country. In The Hague, at Nieuw-Eijk en Duinen, to the present day, a sober monument recalls the incident and the self-sacrifice of the martyr. 
world, in unstoppable cavalcade and bumping from crises in Morocco to Bosnia, helplessly spiralled down towards the abyss. From this perspective, the analysis of objectives and available options of that 'Parliament of Man' 76 and single ever meeting of sovereign nations of a rapidly interlocking world before the constitution of the League of Nations assumes historic dimensions.

Among the 44 nations attending the opening ceremony of the Conference on June 15, 1907 in the Knights Hall of the Houses of Parliament, ${ }^{77}$ Asia was represented by the same nations as in 1899: China and Japan represented the Far East, while Siam, ${ }^{78}$ Persia 79 and Turkey ${ }^{80}$ represented the other parts of the continent. Regrettably, as in

76 The flowery parlance of the day liked to refer to the Conference as "The Parliament of Man, the Federation of the World.' As it was, no concept of 'parliament' figured in the international arena, and this perhaps posed the greatest handicap of all. The conferences were emphatically diplomatic meetings - nothing more, nothing less - among nations that, most of them - and Russia first of all - would never have a legislative, representative body impair the idol of sovereignty. Contrary to parliamentary procedure within the, as a rule, infinitely more coherent domestic sphere, at The Hague, within that crucible of mistrust and decoy that made up world diplomacy, absolute agreement had to be secured, with even the tiniest of nations able to outjockey all others. Given the widely divergent nature of administrations and legal cultures represented, amidst perpetual tension and hidden agendas, small wonder it was that unanimity proved elusive at this first experimenting with a perfectly innovative concept. If only a simple majority vote had sufficed, most projects would probably have passed smoothly into conventions and resolutions.

77 In all, 256 delegates attended the Conference that 'dragged on' as some would have it, for a full four months, due to the sheer number of committees and the insistence of smaller nations to be given the floor on each occasion. Suggestions to delegate representation or vote by proxy were rejected, as was the call for abandonment of all voting. The Conference was instructive in revealing the burden of logistics of democratic procedures at global conferences.

78 The presence of the ancient kingdom of Siam accredited at the Russian court by grace of traditional ties, yet strategically positioned in the midst of conflicting spheres of interest of the great powers was, as in 1899 , mostly symbolic. Siam was represented by major-general Mom Chatidej Udom and captain Luong Bhuvanarth Narübal. As in 1899, Corragioni D' Orelli served as legal counsel. Edouard Rolin-Jacquemyns, to all likelihood, did not attend. The Siamese delegation left few traces in the Conference records.

79 Persia, at that juncture, as stipulated above, was deeply involved in constitutional problems. Therefore, perhaps the most interesting - and indeed baffling - aspect of its presence at The Hague in 1907 is the concluding of the Anglo-Russian Entente in the midst of the Hague Conference. The Entente put an end to decades of rivalry between the two world powers in demarcating their respective spheres of interest from Persia to Tibet in yet another endeavour to curb German expansion in the region. Signed at St. Petersburg on August 31, 1907, typically without the foreknowledge of Persia and the other Asian nations directly involved, the alliance created a storm of indignation in Persia as it received news two weeks later. By treaty stipilation Persia was divided into a northern Russian and southern British zone, separated by a buffer region. In conjunction with the 1892 Franco-Russian Alliance and the 1904 Anglo-French Entente Cordiale the 1907 Entente established the Triple Entente between Russia, France and Great Britain. See R. AdELSON, London and the Invention of the Middle East: Money, Power and War, 1902-1922, 1995. Meanwhile, at The Hague, the Persian delegation was made up of its ambassadors in Paris and The Hague, both veterans of the 1899 Conference, the celebrated Mirza Riza Khan and Mirza Samad Khan. As in 1899 with respect to the 'Geneva' Convention on Land Warfare, in the debate on the 'Geneva' Convention on Naval Warfare, the delegation claimed the red sun instead of the red cross as symbol, in an elegant address by Samad Khan: "It has been remarked to me that in my declaration concerning distinctive signs I should have also recognized the 
1899, and contrary to the impressive debut of the Latin-American continent in 1907, the Asian delegations never came anywhere near concerted action, so as to instill their cultural values and legal concepts on this world assembly. For all the continent's impressive history, no common ideas were ever advanced. Still, nothwithstanding the lack of understanding between the Chinese and Japanese, their status and record in the Russo-Japanese War were very pertinent in The Hague. They were equally active and passive participants, and subject and object of much wealing and dealing. 81

\section{A. China}

The Chinese delegation featured three plenipotentiaries: Lou Cheng Chiang, veteran of 1899; Sien Chun, special envoy at The Hague; and John Watson Foster, former US Secretary of State and grandfather of John Foster Dulles.82 China' s military attach? was Colonel Ting. 83 If the moribund Ottoman Empire, for all its past glory, was called the

inviolability of the Red Cross for foreign hospital ships. I take advantage of the occasion to give this satisfaction to our colleagues of Switzerland. Believing herself perfectly free, after the reservation she made to Article 18 of the Geneva Convention, to employ the flag of the Lion and Red Sun as a distinctive sign of its hospital ships, Persia recognizes reciprocally and formally the inviolability of foreign hospital ships covered by the Red Cross." [24/06, Samad Khan]. See Scott supra note 1, at III 298.

80 The Turkish delegation did not really distinguish itself. As it was, the Ottoman Empire was on the verge of crisis. The following year the revolution of the Young Turks would overthrow the regime and herald a new era, which was to open with years of fierce warfare. The revolution of the Young Turks (1908-1909), along with the subsequent Turko-Italian War (1911-1912), provided the Balkan states with an opportunity to retaliate former oppression. The Balkan Wars (1912-1913, fought between Serbia, Montenegro, Greece, Romania, Turkey, and Bulgaria) disputed the possession of the remaining European territories of the former Ottoman Empire. The Turkish delegation at The Hague in 1907 was headed, as in 1899, by Turkham Pasha. He was escorted by Réchid Bey, his nation's ambassador in Rome; the legal counsel Raif Bey; the military expert Mehemed Said Bey; and vice-admiral and 1899 veteran Mehemed Pasha. With respect to the Red Cross Convention the delegation, as in 1899, claimed the Red Crescent instead of the Red Cross: "The Imperial Ottoman Government has respected the inviolability of the flag of the Red Cross from the beginning and does not to-day ask more than reciprocity for its hospital ships. [...] In giving its adhesion to the Geneva Convention on July 4, 1865, the Imperial Government, like the other Powers, rendered homage to Switzerland by recognizing as the hospital flag an inversion of the Federal colors. It was only when the impossibility of using it for its own hospitals was apparent that it had to adopt the red crescent on a white ground, a sign that it has used for more than thirty years, and which has been recognized and respected in time of war." [16/07, Turkhan Pasha]. See Scott, supra note 1, at III.297. Within a matter of years, Turkey would enter into war with Italy. Three Franco-Italian arbitrations at the PCA issuing from the TurkishItalian War concerned the seizure of merchant ships.

81 We will necessarily limit our comments here to the highlights of China' s and Japan' s involvement, and the discussion of their record during the Russo-Japanese War. For a compact survey of the full Conference see A. Eyffinger, A Highly Critical Moment: Role and Record of the 1907 Hague Peace Conference, 54 NeTH. INT' L L. REV. 197-228 (2007).

82 Foster served as US Secretary of State under President Benjamin Harrison in 1892-1893. In 1895 he gave legal counsel to the Qing Dynasty in drafting the Treaty of Shimonoseki.

83 They were assisted by Secretary Chang Ching-Tong and the Secretary of the Chinese mission in Rome Chao 
'sick man of Europe', the Chinese Empire, by 1907 a mere phantom of its legendary greatness, was duly named the 'sick man of Asia.' In past decades its cramped policy of seclusion had proved counter-productive both in dealing with Western imperialism and Asian nationalism on the rise. Still, for all its vacillating on the verge of collision, the Empire had dispatched some delegates on whom the experience of past decades had not been wholly wasted.

\section{Obligatory Arbitration}

On 5 October Lou Cheng Chiang - to attest to his sensible, level-headed views - had some sobering words in store for the enthusiasts of obligatory arbitration among his fellow-delegates:

"With great attention I have listened to the exceptionally remarkable discourses that have been delivered up to the present time upon the matter that pre-occupies us. On the part of the majority of the members we have listened to optimistic discourses, to discourses full of conviction and full of enthusiasm. The minority has endeavored to show us the other side of the medal. That which is certain is the fact that we are discussing a serious question, a series of articles and of stipulations which, after they have been adopted, would bind our Governments. Sentiment - not to mention sentimentalism - has no place in such a discussion. And even though one of the preceding speakers has sought to act upon the minds of the representatives of the small States by dazzling before their eyes the advantages that would result for the weak from the introduction of obligatory arbitration, I, in my turn, now address myself to these same representatives by giving them the very sincere advice to distrust such a hope. For one case in which the weaker will profit by the institution of obligatory arbitration, there will be ten other cases in which he will feel its consequences and its rigors. It will suffice to recall a certain number of cases when, within the last ten years, small States have had recourse to arbitration with regard to great Powers, in order to realize that this weapon with two edges - for such is international arbitration - is not always in favour of the weak. 84

\section{Contact Mines}

First used as offensive weapons, Japanese anchored mines off Port Arthur had blown up two Russian battleships in April 1904 and taken the life of the popular vice-admiral Makarov. The next month, two of admiral Togo' s foremost battleships were lured into a minefield and sunk with all hands in a matter of minutes. Mines had also taken a heavy toll on neutral merchant men. China had been the first victim of war which, for the

Hi-Chid.

84 See Scott supra note 1, at II 83-84. 
greater part, had been fought over its territory and in its territorial waters. In The Hague, it voiced justified complaints concerning contact mines, those demons of the deep, that had proven wholly uncontrollable weapons. Floating into Chinese and Korean waters like shoals of jelly fish, they had made hundreds of innocent victims among fishermen and required years of sweeping. Years later, Chinese junks were still at jeopardy of being torpedoed by mines drifting astray. China instilled upon the Conference the critical urgency of finally charting that most unprincipled, unruly realm of warfare and was the major drive of the Convention on The Laying of Automatic Submarine Contact Mines [The Hague Convention VIII].

The deadly effect of mines which, anchored or floating on the waves, exploded automatically by contact was uncontested. Still, they were a cheap way of defence for states with a small navy. Neutrals readily applied them to demarcate their territorial sea. In 1906, the Institut de Droit International critically addressed the problem. The 1907 Conference appreciated the urgency, yet scrutiny provoked vehement debate. Britain's proposition, supported by China, was to forbid all mines except within territorial waters or in front of naval ports.85 After two months of debate principles were unanimously adopted for a period of seven years. Mines that were not rendered 'harmless' (or torpedoes that ran loose) were strictly forbidden, 86 and so was laying mines along enemy coasts with the sole purpose of intercepting commerce. 87 These rules also applied to neutrals. 88 Belligerents were obliged to remove mines after the war. 89

\section{The Rights and Duties of Neutral Powers}

In turn for voicing criticism over belligerents, China was itself censured as well. Japan submitted legitimate complaints over China' s 'neutrality', both with respect to land and naval warfare. This debate prompted two mirror-conventions regarding The Rights and Duties of Neutral Powers [The Hague Conventions V and XIII]. ${ }^{90}$ Throughout the

85 Italy claimed exemption for mines that were rendered harmless within an hour of their launch, while the Netherlands and Brazil reserved the use of anchored mines in defence of their neutrality.

86 The Hague Convention VIII art. 1.

87 Id. art. 2.

88 Id. art. 4.

89 Id. art. 5.

90 The position of neutrals in times of war had been problematic ever since the medieval concept of just war had been abandoned. According to that doctrine, admittedly more alive in the minds of theoreticians than pertinent to practice, the prerequisite and legitimation of war was precisely the upholding of the universal social fabric, which precluded neutrality. With the replacement of this doctrine with formal criteria of warfare in early modern times, a law of neutrality was gradually developed, even if up to the Napoleonic era the rights of belligerents took distinct precedence over those of neutrals. In addressing the issues the Conference complied with a Voeu expressed by the 1899 Conference. In the debate, the 1875 Rules of Washington compiled by the Institut served as guidance. 
conflict, Japan and Russia had trampled the Chinese countryside. Russia had abused Chinese territory and compromised its neutrality by installing a radio station on Chinese territory (Chefoo), to secure communications between the besieged Port Arthur and St. Petersburg. The objectives set in 1907 were as modest as they were pragmatic: to strike a balance between the interests of belligerents and the rights and duties of neutrals, and to convert into a solid code of law as many usage the powers would agree upon, its stipulations balancing usage and doctrine. The Convention linked the duty of belligerents to refrain from certain acts to the express duty of neutrals to prevent these acts from occurring on their territory. Compromise was the keyword and the Convention at best the opening move of a delicate chess-game.91

The position of neutrals in naval war had been first seriously addressed in the 1856 Paris Declaration. 92 If three wars had amply demonstrated Paris' inadequacy,93 1907 revealed the persistent controversy of thought. Propositions bespoke geographical and technological bias rather than global humanitarian principles. During the war, the Russian fleet had abused Chinese and other nations' hospitality on several occasions. The Russian gun-boat Manjur had been lying in Shanghai harbour when war broke out. With a Japanese cruiser in waiting, it refused to leave port, embarrassing Chinese authorities; it was finally dismantled on the spot. Again, twice after decisive Japanese naval victories, unseaworthy Russian cruisers had taken refuge in Manilla and German and American ports for repairs. Articles 13-15 and 24 concluded upon leave within 24 hours from any port in the immediacy of the war theatre, or internment for the full duration of the war. ${ }^{94}$ Other neutral powers also had trespassed the law in many ways, to their profit mostly, as in handling contraband and secretly assisting one of the belligerents. 95 Japan had seriously questioned China' s integrity.

91 The Conference decided on the inviolability on principle of neutral territory [Convention V, Art. 1]. It highlighted the prohibition of transit and transport across neutral territory [Art. 2] or the installation of radio and telegraph installations [Art. 3]. The latter stipulation, first formulated in the 1906 Wireless Telegraphy Regulation of the Institut, was precisely actuated by Russian activities on Chinese territory (Chefoo) during the 1904 siege of Port Arthur. Art. 10 stipulated that the forceful repulsion of intruding belligerents should not in itself be deemed a hostile act.

92 The 1871 Anglo-American treaty of Washington best represented diplomatic practice of the period.

93 The Spanish-American (1898), Anglo-Boer (1899-1902) and Russo-Japanese War (1904-05).

94 Detailed rules were elaborated in case ships from both parties were calling in neutral ports simultaneously Art.16].

95 Debate went on for three months. From it emerged the guiding principle of unequivocal respect for the sovereign rights of neutral powers [Convention XIII, Art.1], a duty countered by the requirement of strictest impartiality on the part of the latter [Arts. 9, 25]. Thus, for their waters and territory to be held inviolable, duties as well as rights ensued for neutrals. It was established, with reference to cases like that of the General Armstrong (1814), the Florida (1864), and the Ryeshitelmi in the Russo-Japanese conflict that a prize taken within the territorial waters of a neutral power was to be released to it and interned. When no longer within 


\section{B. Japan}

In 1899 Japan' s approach had been fairly constructive. It had signed all six Conventions unreservedly. By 1907, the wiser from sad experience, it had a definity more nuanced view on the reach and pertinence of legal concepts in geo-politics. The previous decade had told it to preferably add strength of arms to legal argument. Indeed, it felt that by its recent devastating military victory it had far more impressed Western observers than by its undisputed legal expertise. Japan's authority and interest in the debate were no longer challenged.

The Japanese delegation was made up of plenipotentiary Keiroku Tsudzuki, an expert diplomat who showed political tact, legal competence and social adroitness throughout, and Aimaro Sato, its minister at The Hague. They were escorted by three technical delegates: military expert Akyama Yoshifuru, a cavalry major-general; naval expert Hayao Shimamura, a rear-admiral; and Japan's long-standing American legal counsel and member of the PCA, Henry Willard Denison. 96

Tsudzuki's position was not to be envied. Back in Japan, advocates of the disarmament and arbitration paragraphs were engaged in a bitter fight with militarism on the rise, also within the foreign ministry. By 1907, the country was ideologically divided into a pro-English and a pro-German faction. Precisely on disarmament and arbitration British and German policies were at loggerheads. Being himself inclined towards the British side, yet wooed by Germany throughout the full four months, Tsudzuki had to manoeuvre carefully. This is why, with respect to the overarching issue of obligatory arbitration, when put to the test, and with the help of some gentle French push, Japan thought wise to abstain from voting. ${ }^{97}$ In June 1908, it readily ratified the other twelve Conventions, merely withholding its consent from the controversial Declaration on Balloons.

\section{War and Peace}

Tsudzuki made various addresses to the Plenary to demonstrate Japan's appraisal of world affairs. On 27 July he made recommendations regarding the status of neutrals

its waters, the prize should, at the neutral power's express demand, be surrendered [Art. 3]. See Higgins supra note 1 , at $462-63$.

96 Henry Willard Denison (1846-1914) was a former US vice-consul in Yokohama who served the Japanese Foreign Ministry as legal adviser for well over three decades (1880-1913). He drafted the Japanese submissions to the 1895 Treaty of Shimonoseki and the British-Japanese friendship treaty, attended the 1905 Portsmouth conference on the staff of Baron Komura, and was a member of the PCA for Japan. He was the first foreigner to receive the Grand Cordon of the Rising Sun.

97 At The hague, obligatory arbitration was backed by a great majority of nations, yet, in a historic error of judgment, voted down by Germany and Austria-Hungary and some of their Balkan satellites. 
and belligerents in light of Japan' s experience in previous years:

\begin{abstract}
"The progress of civilization and the development of sentiments of justice and humanity make war, as time goes on, more and more the exception in the intercourse of States. Being an abnormal condition, it should be confined within the narrowest limits possible. There are not at present clear and universally recognized rules governing the relations between neutrals and belligerents with regard to the questions that have been laid before us, and history teaches us that the divergent and frequently conflicting interpretations and practices adopted in the past by different countries have been one of the most fruitful causes of international irritation and recrimination. It would therefore be desirable to remove as far as possible the dangers arising from this state of affairs." 98
\end{abstract}

\title{
2. Formal Declaration of War
}

However, for all its lofty statements, Japan was seriously criticized precisely on behalf of its conduct in war, and this time no Ariga or Takahashi could help it out. Even if the brunt of international criticism was borne by Russia, Japan's 'surprise' attack on Port Arthur and its submitting a declaration of war after the act, much similar as in 1942,99 provoked widespread censure - otherwise on dubitable legal grounds, as fairness compels to say. In the absence of an unequivocal legal regime, Russian indignation was perhaps somewhat selective.

Divergent 19th century doctrine on the desirability and legal status of formal declarations of war - or, in their conditional variant, ultimatums - mirrored the bewildering inconsistency of state practice to which Tsudzuki referred in the above quote.100 Still, the Franco-Prussian clash had opened with a formal declaration - and perhaps more to the point: so had the 1894 Sino-Japanese War - while the Boer War was preceded by an ultimatum. Westlake called "an attack which nothing had foreshadowed 'infamous' and a gross violation of international law." 101 Still, the Japanese position was that by separating diplomatic relations and recalling its minister from St. Petersburg, it had given ample and timely warning.

In view of Russia's fierce protest in 1904, the Institut, as ever keen on keeping the pulse of the law, had enquired the issue and guided the 1907 debate which issued in

98 See Scott supra note 1, at III 579.

99 The formal Declaration was handed over in St. Petersburg a matter of hours after the opening of the torpedo raid.

100 European powers, including France and Britain, ignored the concept at will, as the British General Maurice had pointed out in an embarrassing overview of European history. Precisely in the past two centuries the previously prevailing formal declaration had gradually fallen into disuse, and as it was, John Bassett Moore or Hall, to mention just two authoritative experts, never saw fault.

101 J. WESTLAKE, INTERNATIONAL LAW, 2 vols. (1904-7). 
Convention III regarding The Opening of Hostilities. In advocating the principle, whether as declaration or ultimatum, the Institut, tellingly, drew attention to the 'common interests of states' and 'the spirit of loyalty.' Inasmuch as the declaration's objective was to forestall surprise attack, the Membres recommended the expiry of a delay sufficient to preclude all misunderstanding. 102

Intriguingly, in the course of the debate, the Chinese delegate Ting, to show that the Empire's political impotence was not due to lack of acuteness, put two pertinent and downright embarrassing questions to the Plenary. In a seemingly innocent query he wondered what, in this respect, the distinction might be between war and 'military expeditions.' This was an unveiled reference to Western unprovoked aggression in China without fair warning. In a second query he wondered what would happen when China faced a declaration of war but did not intend to fight - once more a query brimmed with innuendo. No appropriate answers were ever put on record - and China never bothered to sign the Convention.

\section{Naval Warfare}

The Russian decision to put the complexities of naval warfare on the agenda had been a bold one.103 Precisely the bitter experience of the Russo-Japanese war had instilled the critical urgency of charting that most unprincipled, unruly realm. The very nature of war at sea and the silence of the law conspired to make naval warfare a gruesome business, presenting as little hope for salvage as for mercy.104 The bloody naval battles at the Yellow Sea and the Strait of Korea had pointed that out. Still, it was a veritable mer á boire the Conference addressed, full of technical pitfalls and political susceptibilities. Its substance was divided over three Commissions. 105 The debate was

102 Arrticles 1 \& 2 of the Hague Convention III insisted on "previous and unequivocal warning" [Art. 1] and notification of neutral powers "without delay" [Art. 2]. The Netherlands suggested a delay of 24 hours as "accorded even by Napoleon," to laxen the permanent state of mobilisation of the nations. Russia concurred, to enable overtures for reconciliation by third parties. These propositions were rejected. As a consequence, a security valve against surprise attack was lost.

103 It lived up to the desire expressed in its Conference programme to preferably examine "pressing" issues "arisen from the experience of the years just past" rather than initiating a philosophical debate.

104 For centuries on end - and notwithstanding the Consolato del Mare, Rôles d Oléron and Laws of Wisby piracy and reprisal, public no less than private, had constituted the universal plague of the 'magnus intercursus' of nations in times of peace and war alike. Guerre de course and lettres de marque lived side by side with Courts of Admiralty and Angarie Laws. Conflicts between belligerents and neutrals over issues of prize law and contraband, the immunity of private property, the definition of continuous voyage, or the interpretation of infection hostile and droit de cabotage were ubiquitous. The competence of national prize courts and the laws they applied (but rarely published) was generally contested. In the absence of consistency, and with whatever norms were enforced liable to controversy, objectivity was hard to attain.

105 War at sea was discussed by the Third Commission, maritime law by the Fourth Commission, the Prize Court by the First Commission. 
more in the order of a first salute than serious tackling the many riddles involved. All too keen perhaps to finally do away with the embarrassing driftwood of centuries, delegates clearly overplayed their hand. At the end of the day, they had to admit they had bitten off more than they could chew. Its mostly abortive examination was continued in London two years later, in a téte-á-téte of the great naval powers. 106

\section{The Geneva Convention}

Irregularities in the Russo-Japanese War also dictated the Adaptation of the Principles of the Geneva Convention to Maritime War [Convention X].107 The Conference engaged in an uphill battle against flagrant, wholesale abuse. Able men were transported under the veil of sick and wounded; the latter, while first seeking shelter, after recovery eagerly took up arms. Notoriously, in 1905, the Russian ship Orel had first assisted in hostile operations and taken able-bodied prisoners from a captive merchantman, then to be turned into a hospital ship.108 Russia and Japan had serious altercations over the three vertical stripes of light (white, red, white) which Russia proposed for its hospital ships to carry at night. The idea was controversial as hospital ships carrying lights could easily betray the presence of a fleet. Actually, this is what occurred in May 1905, when a hospital ship in Admiral Rozhestvensky's ill-starred Baltic Fleet, by carrying light at night, gave away the fleet' s position, thus enabling admiral Togo, by the first ever use of wireless telegraph, to surprise his opponent in Tsushima Strait and destroy the pride of Russia's navy virtually within an hour. Conversely, during the war, warships, making illicit use of red cross lights, sneakily made their escape from danger. 109

106 In blocking progress, the natural enmity between the world's leading naval and military power, Great Britain and Germany, naturally asserted itself. Yet, more pertinent still perhaps was the ideological incongruity of whatever little the Continental and Anglo-Saxon law traditions had added up to. Also, by 1907, the astounding progress of technology had obliterated all previous thought, as amply demonstrated by the 1898 Spanish-American and 1904 Russo-Japanese wars.

107 Back in 1868, mostly abortive attempts had been made to have the humanitarian principles that governed the 1864 Geneva Convention adapted to naval warfare. The domain had remained virtually tabula rasa until the 1899 Conference dealt with the issue. In 1906 the 1864 Convention had been upgraded in Geneva, and it was now the task of the 1907 Conference to upgrade the work of 1899 on naval war in that light. These were stubborn issues and abuse lurked around every corner.

108 See Higgins supra note 1, at 385-86.

109 The Commission felt forced to enter into much detail. It amply discussed flags and distinguishing marks of hospital ships [Arts. 5-6]. Warships of belligerents, it was decided, were at all times entitled to reclaim shipwrecked from hospital ships [Art. 12], whereas neutral ships were held to detain shipwrecked to prevent their re-entering service [Art. 13]. Each and every stipulation was triggered by irregularities in the RussoJapanese war. Above all, the inviolability on principle of staff of hospital ships and of sick and wounded was firmly established. However, as Renault wisely observed, the strictest observance of rules by hospital staff themselves was vital to their own functioning - and that of the Convention. As in 1899, instead of the cross, Persia claimed the sun or lion and Turkey the crescent. 


\title{
5. Japanese Appraisal
}

The above must suffice as just a few pointers to illustrate the impact of the RussoJapanese war on the 1907 Conference, and therefore the pertinence of Japan as a civilized nation in the international arena. In the closing Plenary, on 18 October, 110 Tsudzuki showed himself satisfied with the work done by the Conference in the humanitarian sphere:

\begin{abstract}
"As the representative of a Power that several years ago experienced to the utmost the horrors of modern war, I believe that I am in a better situation than anyone else to express the feelings of appreciation of the eminently humanitarian labors of this Conference. Moreover, as I belong to the country at the greatest distance from the seat of this Conference, it is my privilege to testify to the sentiment of gratitude that animates all peoples, even at the opposite end of the globe..."
\end{abstract}

\section{He extolled the merits of Dutch Vice-President De Beaufort:}

"It is a very pleasant duty for me to render justice to his tact, to his spirit of conciliation and impartiality, and above all to his rare and beautiful characteristic of self-effacement, with which he collaborated in the delicate and difficult labors of the presidency of the first truly cosmopolitan Conference in history. $[\cdots]$ In rendering this praise to our vice president, I cannot forget that Mr. De Beaufort is also the first delegate of the Netherlands and thus forms the prudent and valuable link between the Conference and the Government which accorded us such generous hospitality for four months, a hospitality in keep with the chivalric name of the hall where we are meeting to-day. 111

He then added an interesting observation:

But above all, Mr. President, it is to you, the representative of the directing force of this assembly, I permit myself to address my most sincere thanks on behalf of my country which, up until the end of the last century gave a very rare example of profound and continuous peace for three hundred years; in the name of my country that has always placed the calm and enduring happiness of peace high above the troubled and passing glory of war.

In conclusion, I wish to express my thanks to you, gentlemen, for the cordial welcome you have accorded to one of your younger brothers in this truly international fraternity; you have recognized that we are younger relations, that we

110 See Scott supra note 1, at I 591.

111 Tsudzuki was not alone in his praise for De Beaufort which, as many perceived, was meant if anything to belittle the merits of the Plenary's Russian president De Nelidov. 
are with you heart and soul in your century-old devotion to the great cause of peace and civilization.

Thus ran the final chord of the nation that in years to come, like so many nations before and after it, temporarily forgetful of its tradition of centuries, was allured by the Siren of power to indulge in short-lived military pride.

\section{Conclusion}

The above overview has presented us with fifty crucial years in the history of three proud nations of the Far East. Nations that shared among themselves a tradition and civilization far older, and during long stretches of history far superior to Western traditions. These three nations reacted in their own individual and indeed very different ways, and sadly enough not by making a common stand, on the onslaught of impressions - ranging from intimidation to use of force and from advanced technology to incomprehensible legal concepts - that took them by surprise and hit them as by thunderbolt around 1850.

The oldest, wisest nation sadly shook its head and preferred not to see. For all the empathy with its choice, that proved no option. It was an historic error for which it paid costly with humiliation and an identity crisis of decades on end. The second nation, irresolute, experienced the havoc wrought to the "small fry" when caught in the crossfire of the Great.

The third nation, the sea-faring one, went the other way. In a process described by Anand112 as running from humiliation to assimilation to defiance to confrontation it showed itself susceptible to new impressions, adapted to circumstance and assimilated to the point of almost denying its roots and alienating itself from its sister-countries. It first took the path of international law, only to find out that, at the end of the day, right without might stood helpless in the cauldron of decoy of global politics. It then took the path of power, to its doom. Yet who is there to tell where ran that hidden byway to success and competitiveness without shame or loss of identity, that track that likewise remained hidden to the nations, peoples and tribes of the American and African continents when they were struck and unbalanced by the same phenomenon? No Western ship, to be sure, ever carried that treasure in its cargo. 